\title{
Impact of Cash Deals and Related Industry Merger on Synergies Gains: A Case of Indian M\&A
}

\author{
Anjala Kalsie $P h D$ \\ Assistant Professor \\ Faculty of Management Studies \\ University of Delhi, India \\ E-mail: kalsieanjala@gmail.com \\ Neha Singh \\ Research Scholar \\ Faculty of Management Studies \\ University of Delhi, India \\ E-mail: nehasingh.usms@gmail.com
}

Received: August 17, 2020

Accepted: August 30, 2020

Online Published: September II, 2020

doi: I0.4628I/ijfb.v4i2.760

\begin{abstract}
A firm's financial attributes play an essential part in the merger decision. The present paper attempts to improve the existing literature on assessing M\&A activity in Indian corporate. This research paper aims primarily to analyze the (a) Synergies realized when the mode of payment in the merger deal is cash, (b) impact on bidder liquidity when payment is made in cash (c) Synergies realized when both target and acquirer in the deal belong to related industry, i.e. the merger is horizontal and (d) assess the impact on bidder leverage when payment is made in equity. The paper has analyzed a panel of I20 major Indian M\&A deals from 2005 to 2015, having three years of data pre and post-merger. Instrument Variable Probit Regression analysis has been employed in the study. The key results from the analysis show that in case of payment method in the deal being cash, M\&A appears financially favorable for the bidder companies. The results of the empirical analysis of the study do support the generation of synergies in the case of horizontal mergers. The combined firm has also found to have lower liquidity for Indian Mergers \& Acquisitions. Significant results have also been obtained for the leverage variables indicating fewer borrowings for the merged firm.
\end{abstract}

Keywords: M\&A Activity, Synergies, Variable, Regression Analysis, Cash Deals, Industry Relatedness.

JEL Classification Codes: G34, C35, M4I.

\section{Introduction}

Corporate restructuring involves any change in the assets or capital structure of a company or its ownership through an inorganic route (Godbole, 2013). Such a change can be effected through either acquisition of a company, merger or demerger of/into two or more companies, delisting or selling off a company, or its important assets. Mergers \& Acquisitions is the primary mean of corporate restructuring. A merger can be defined as the consolidation of the resources, liabilities, and operations of two or more firms into one, where payment is made in the form of the merger company's equity shares or debentures or cash or else a hybrid of the payment methods listed above (Beena, 2000). Some of the main objectives to undergo a merger are expanding into new markets, considerable cost savings, and knowledge sharing as well as risk-sharing. However, the prime objective of undertaking any form of restructuring is to gain synergies generated out of the combination. Synergy is the potential benefit that is achieved post the amalgamation. Apart from the lure of quantum growth associated with the mergers, there are many other motives for which companies resort to M\&A, financial and operating synergies being the most important out of them, which add to the enterprise valuation (Sudarsanam, Holl, \& Salami, 1996).

Synergies are of two types - revenue-generating and cost reduction with the former being more difficult to achieve (Cullinan, Le Roux, \& Weddigen, 2004). Financial synergies involve combining both target and acquirer companies' balance sheets to achieve improved financial parameters (Godbole, 2013). Operating synergies are the ones that are generated due to improved operating efficiencies of merged entities, which is majorly due to improved tax benefits or investment cutbacks (Huyghebaert \& Luypaert, 2013; Hamza, Sghaier, \& Thraya, 2016; Loukianova, Nikulin, \& 
Vedernikov, 2017). The synergies generated are not always positive, and firms can even experience negative synergies, which create the exact opposite outcome to that of positive synergies. In the case of negative synergies, the sum is less than its parts due to value erosion. The theories of diseconomies of scale and scope are used to explain the adverse effects of negative synergies (Harding \& Rovit, 2004).

The M\&A deals have become common in India in the last two decades. In the post-liberalization period, though they had not been uncommon before, but the frequency was less (Bhoi, 2000). The liberal economic policy by the Government post-1990s incentivized companies to undergo expansion, diversification, up-gradation of technology, and entering into newer geographical areas. Several firms deemed it necessary to combine with related business units and subsidiaries to achieve cost efficiency and improved production. The quantum of deals in India has seen a steady increase since 2013 with a similar increase in the total value of deals undertaken. In 2015, companies announced over I200 transactions with a total value over 5I billion USD. The number of transactions increased moderately by 15.6 percent compared to 20I4, while the value has increased by 63 percent (M\&A Statistics by Countries-Institute for Mergers, Acquisitions, and Alliances (IMAA), 2019).

The financial performance and also the assessment of mergers \& acquisitions have dwelled well in the field of financial and industrial economics. Despite this, there is debate if mergers \& acquisitions boost corporate efficiency. The present study explores the performance of the acquirer and whether synergies are achieved in the post-merger time period, when the mode of payment for the transaction is cash. Similar gains are analyzed for horizontal mergers as well. The present study analyses I20 deals of Mergers \& Acquisitions which took place between 2005 and 2015 for the Indian Corporate. To estimate the relationship, the Instrument Variable Probit Regression model is applied in the study.

The paper is organized into six sections, which are as follows. Literature review of the different methodologies used in the existing studies and their findings have been discussed in Section 2. Section 3 gives the objective and hypothesis of the present study. Section 4comprises the research design, variables, data source, and methodology employed in the research. Section 5 pertains to the results based on the econometric analysis. The paper ends with the conclusion and implications presented in Section 6.

\section{Literature Review}

Majority of studies to date in Mergers \& Acquisitions relate to economic costs \& benefits accrued to acquirers and targets in the post-merger scenario. Few studies deal with the stock market returns and misvaluations. Majorly, the methodology of event study has been used in the existing literature, which assesses the impact of the merger in the short-run $([-\mathrm{I},+\mathrm{I}],[-$ $5,+5]$ ), i.e. to investigate the implications of the announcement of M\&As on the wealth of the shareholder. They have concluded either significantly negative abnormal returns or insignificant abnormal returns in the short-run (Andrade, Mitchell, \& Stafford, 200I; Bruner \& Mullins, 1987; Bradley, Desai, \& Kim, 1988; Byrd \& Hickman, I992; Kaplan \& Weisbach, 1992; Healy, Palepu, \& Ruback, 1992; Lang, Stulz, \& Walkling, I989; Mulherin \& Boone, 2000; Servaes, I99I; Smith \& Kim, 1994). Whereas the result of the long-run event studies studying post-merger returns after three years have pointed out that firms experience negative abnormal returns (Andrade, Mitchell, \& Stafford 200I; Lahey \& Conn, I990; Limmack, I99I; Loughran \& Vijh, I997; Mitchell \& Stafford, 2000; Rau \& Vermaelen, 1998).

Despite the strength of the research in this area, there is a lack of consensus on the stimulus mergers and acquisitions have on the economies of the countries in which they occur, especially on the targeted corporations. In the past, several studies have sought to examine the costs and gains of mergers and acquisitions. However, the conclusions of these investigations are so varied that it is impossible to arrive at a clear consensus. Although some research supports the benefits accrued to the acquired firm, no consensus can be derived on the benefits obtained by acquiring companies' shareholders (Cummins \& Weiss, 2004; Mohanty \& Mishra, 20I I).

There are studies, which assess the shareholder wealth by accounting performance through performance measures like operating cash flows to sales, operating cash flows to total assets, return on assets and operating income over total assets; and they come to a variety of conclusions. While some studies like Andrade, Mitchell, and Stafford (200I); Ramaswamy and Waegelein (2003) shows the gain in accounting performance post-acquisition; there are studies like Ravenscraft and Scherer (20I I)which show retrogression of performance post-M\&A.

Studies undertaking the assessment of synergies in terms of operating performance after undertaking Merger \& Acquisition have shown mixed results. While studies like Linn and Switzer (200I); Moeller and Schlingemann (2004); Switzer (1996); Parrino and Harris (I999); Powell and Stark (2005) looking into pretax cash flows have shown an increase in post-acquisition cash flows; there are studies which shows an overall decline in cash flow (Kruse, Park, \& Suzuki, 2003), lower profitability (Meeks, 1977), a significant decline in the ROA (Yeh \& Hoshino, 2002; Dickerson, Gibson, \& Tsakalotos, 1997)and insignificant improvement in operational efficiency following the acquisition by the acquirer (Ghosh, 2001; Herman \& Lowenstein, I988; Lev \& Mandelker, I972; Sharma \& Ho, 2002).

Existing literature in financial synergies studying the existence and extent of financial synergies have suggested deterioration in post-M\&A profitability measure in respect of EPS (Hogarty, 1970), Return on capital equity (Harris, Franks, \& Mayer, 1987), ROE (Yeh \& Hoshino, 2002), liquidity, profitability, and solvency ratios (Pazarskis, Vogiatzogloy, Christodoulou, \& Drogalas, 2006). The results suggest that the result of the acquisition of the profitability of the firm is detrimental (Dickerson, Gibson, \& Tsakalotos, 1997). However, an analysis of the financial efficiency of selected Indian financial institutions showed that long-term value was created and financial performance improved for the acquired firm post-acquisition; but not on all parameters (Sinha, Kaushik, \& Chaudhary, 2010). 
The mode of payment is also one of the determinants of the synergies gained in the post-acquisition. Linn and Switzer (200I) suggest that the operating efficiency of the combined firm in the US have a propensity to be greater in cases where cash was the key mode of payment. Acquisitions financed by stocks are associated with smaller synergy changes than when the payment method is in cash (Carline, Linn, \& Yadav, 2005; Ghosh, 200I). Statistical findings have consistently shown that the target and the acquirer's share prices react more favorably to a cash proposition than to a stock purchase at the time of the initial announcement of the bid (Peterson \& Peterson, I99I; Carnes, Black, \& Jandik, 200I; Bouwman, Fuller, \& Nain, 2009).

Another critical issue in the literature is how the horizontal acquisition affects the efficacy of the acquirer, by influencing synergies within the combined organization. It is believed that horizontal acquisitions provide substantial synergy opportunities, because of the similar institutional climate of the acquirer and the target (Farjoun, 1994; Barai \& Mohanty, 2014). At the same time, vertical acquisitions are hypothesized to offer lesser potential for synergy (Chatterjee, 1986). It is increasingly being recognized that the complementary resources of varied industries may also provide the major potential for synergies (Barkema, Baum, \& Mannix, 2002; Harrison, Hitt, Hoskisson, \& Ireland, 2000; Tanriverdi \& Venkatraman, 2005). Meta-analysis results, however, suggest no significant association between the performance of the acquirer and similarity of the industry of the acquired firm (King , Dalton, Daily, \& Covin, 2004).

An overview of the prominent studies showing the reported variables and the methodology adopted is given in Table I.

Table I. Summary of Literature Review

\begin{tabular}{|c|c|c|}
\hline Existing Literature & $\begin{array}{l}\text { Methodology } \\
\text { adopted }\end{array}$ & Key Variables Used in the study \\
\hline $\begin{array}{l}\text { Varaiya and Ferris (1987), Lang, Stulz and Walkling } \\
\text { (1989), Bradley, Desai, and Kim (I988), Asquith, } \\
\text { Bruner, and Mullins (1990), Healy, Palepu, and } \\
\text { Ruback (1992), Byrd and Hickman (I992), Mulherin } \\
\text { and Boone (2000), Kaplan and Weisbach (I992), } \\
\text { Andrade, Mitchell, and Stafford (200I), Kuipers, } \\
\text { Miller and Patel (2002), Chari, Ouimet and Tesar } \\
\text { (2004), Huyghebaert and Luypaert (2013), Barai and } \\
\text { Mohanty (2014) }\end{array}$ & Event Study & $\begin{array}{l}\text { Acquirer Return, Free Cash Flow, Premium, } \\
\text { Leverage, Relative Size, Announcement } \\
\text { Returns, Leverage, Return On Asset, Sales, } \\
\text { Market Capitalisation, EBITDA To Sales, } \\
\text { Cumulative Average Abnormal Returns }\end{array}$ \\
\hline $\begin{array}{l}\text { Hogarty (I970), Philippatos, Choi, and Dowling } \\
\text { (1985), Ramaswamy and Salatka (1996), Ravenscraft } \\
\text { and Scherer (2011) }\end{array}$ & $\begin{array}{l}\text { Univariate } \\
\text { Regression } \\
\text { Analysis } \\
\end{array}$ & $\begin{array}{l}\text { Operating Cash Flow Return On Assets, } \\
\text { Earning Per Share, Operating Expense Ratio, } \\
\text { Operating Income Over Assets }\end{array}$ \\
\hline $\begin{array}{l}\text { Ghosh (200I), Morag (20II), Tanriverdi and } \\
\text { Uysal(20I I), Barai and Mohanty (20I4) }\end{array}$ & $\begin{array}{l}\text { Multivariate } \\
\text { Regression } \\
\text { Analysis }\end{array}$ & $\begin{array}{l}\text { Integration Effectiveness, } \\
\text { Relatedness, Organizational Culture, } \\
\text { Synergy Potential, M\&A Success, Cash } \\
\text { Flows To Total Assets, Profitability, Return } \\
\text { On Asset, Leverage, Growth Of Net Assets, } \\
\text { Leverage, Free Cash Flow, Relative Size, } \\
\text { Method Of Payment, Book Leverage, IT } \\
\text { Capability Of Acquirer, Relative Acquisition } \\
\text { Size }\end{array}$ \\
\hline $\begin{array}{l}\text { Cudd and Duggal (2000), Kumar and Rajib (2007), } \\
\text { Basu, Dastidar, and Chawla, (2008), Ismail (20II), } \\
\text { Bena and Li (20I4), Ismail, Dbouk, and Azouri } \\
\text { (20I4), Fich Nguyen, and Officer (20I8) }\end{array}$ & Logit Analysis & $\begin{array}{l}\text { Liquidity Ratio, Growth Rate, Market To } \\
\text { Book Ratio, Total Assets Ratio, Sales, Cash } \\
\text { Flow, Price To Earnings Ratio, Leverage, } \\
\text { Tobin Q, Cash Payment, Relative Size, Log } \\
\text { Assets }\end{array}$ \\
\hline $\begin{array}{l}\text { Harris (1982), Pastena and Ruland (1986), Harford } \\
\text { (1999), Bernile (2005), Mooney and Shim, (2015), } \\
\text { Chira, García-Feijóo, \& Madura (2017), Tremblay } \\
\text { (2017), Bernile and Lyandres (2019) }\end{array}$ & Probit Analysis & $\begin{array}{l}\text { Size, Liquidity, Leverage, Profitability, } \\
\text { Growth, Price/Earnings ratio, Dividend } \\
\text { policy }\end{array}$ \\
\hline
\end{tabular}

Source: Authors' representation based on the previous literature

\section{Objective and Hypothesis}

The present paper aims to assess if synergies are gained post the merger for the acquirer. The study examines I20 M\&A deals for the Indian Corporate, which took place between 2005 and 2015. Certain parameters have been selected to effectively represent the synergies gained (Appendix B). The mergers have been selected from a broad period to ensure representation from different business cycles. The primary objective of the present study is to analyze (a) the Synergies realized when the mode of payment in the merger deal is cash, (b) impact on bidder liquidity when payment is made in cash, 
(c) Synergies realized when both target and acquirer in the deal belong to related industry, i.e. the merger is horizontal and

(d) impact on bidder leverage when payment is made in equity.

The models developed in the paper are listed in the table below.

Table 2. Models employed in the study

\begin{tabular}{|c|c|c|c|}
\hline Objectives & Hypothesis & $\begin{array}{l}\text { Dependent Variable } \\
\text { (Binary Variable) }\end{array}$ & Equations for each model \\
\hline Model I & $\begin{array}{l}\text { H.: When payment } \\
\text { is made in cash, } \\
\text { more synergies are } \\
\text { generated. }\end{array}$ & $\begin{array}{l}\text { Mode of Payment is } \\
\text { Cash }\end{array}$ & Payment_Cashit $=\alpha+\sum_{j=1}^{j} \beta_{j} X_{i t}^{j}+\gamma_{\mathrm{it}} Z_{\mathrm{it}}+\varepsilon_{\mathrm{it}}$ \\
\hline Model 2 & $\begin{array}{l}\mathrm{H}_{2} \text { : When bidder } \\
\text { liquidity is high, } \\
\text { payment is made in } \\
\text { cash. }\end{array}$ & $\begin{array}{l}\text { Mode of Payment is } \\
\text { Cash }\end{array}$ & Payment_Cashit $=\alpha+\sum_{j=1}^{j} \beta_{j} X_{i t}^{j}+\gamma_{\mathrm{it}} Z_{\mathrm{it}}+\varepsilon_{\mathrm{it}}$ \\
\hline Model 3 & $\begin{array}{l}\mathrm{H}_{3} \text { : When merger \& } \\
\text { acquisition take } \\
\text { place in the related } \\
\text { industry sectors, } \\
\text { more synergies are } \\
\text { generated. }\end{array}$ & $\begin{array}{l}\text { Relatedness of } \\
\text { Industry }\end{array}$ & Industry_Relatednessit $=\alpha+\sum_{j=1}^{j} \beta_{j} X_{i t}^{j}+\gamma_{\mathrm{it}} Z_{\mathrm{it}}+\varepsilon_{\mathrm{it}}$ \\
\hline Model 4 & $\begin{array}{l}\mathrm{H}_{4} \text { : When bidder } \\
\text { leverage is high, } \\
\text { payment is made in } \\
\text { equity. }\end{array}$ & $\begin{array}{l}\text { Mode of Payment is } \\
\text { Equity }\end{array}$ & Payment_Equityit $=\alpha+\sum_{j=1}^{j} \beta_{j} X_{i t}^{j}+\gamma_{\mathrm{it}} Z_{\mathrm{it}}+\varepsilon_{\mathrm{it}}$ \\
\hline
\end{tabular}

Where $\mathrm{X}$ is the independent variable and $\mathrm{Z}$ is our instrument variable.

\section{Data and Methodology \\ 4.I Data Description}

The study considers an unbalanced panel data of the I20 Mergers\& Acquisition deals which took place in India from 2005 to 2015. Data of seven years ( 3 years post-Merger, year of Merger, 3 years pre-Merger) has been taken for each deal. Hence, the period of data used in the study is from 2002 to 2018. The study has excluded non-listed acquirer firms, and also financial and banking companies because they have distinct accounting, operational, and risk-based features. The highest representation for the acquirer in the deals under consideration is in the industrial sector with 30 deals. The basic Materials sector has been most represented for the target (Appendix A).

Accounting and financial data, which is used as regressors and dependent variables for the probit analysis, i.e. Mode of Payment (cash or equity) and Relatedness of Industry have been compiled from Bloomberg. Appendix B defines the variables that the study uses. For the present study, the combined entity's performance in the post-acquisition period has been equated with that of target and acquirer $(\mathrm{A}+\mathrm{T})$ entities. For an appropriate comparison, each variable is deflated by tangible assets of the considered firms and thus eliminating the size effect (Healy, Palepu, \& Ruback, I992). (Note I)

The paper has also measured operating cash flow returns on assets to assess operational efficiency changes, as suggested by Healy, Palepu, and Ruback (1992). Conceptually, cash flows have been concentrated as they reflect the real economic gains that are generated by assets. Operating cash flows were defined as the addition of sales, goodwill expenses, and depreciation; followed by deduction of the selling and administrative expenses and cost of goods sold. As the amount of economic gains is influenced by the assets used, cash flows have been scaled by total assets to form a measure of return that can be measured over time and even across the firms.

\subsection{Methodology}

The present study uses the two-step Instrument Variable Probit regression for empirical analysis instead of conventional multivariable regression analysis. Binary data models that are of a dichotomous type assume a binomial distribution for the dependent variable which are well described by Awogemi and Oguntade (2012); Gujarati, (2004); Krzanowski (1998); Hollander and Wolfe (1973). The assumptions of normality such as disturbance terms and observations are normally distributed; homogeneity of variance; normality measures are null. The dichotomous quality of dependent variables collapses the assumptions of Ordinary Least Square (OLS).

Variables used in the study for the firms are correlated to each other. This can be observed from the fact that if we have included Net Income in the model, we cannot say that a firm's Net income is not impacted by the EBITDA or total assets of the firm which has not been considered in the equation employed. It suggests that in such a model EBITDA or total assets will be represented in the error term. And hence the error term shows a correlation with the model's independent 
variables. This kind of problem is distinctive in such type of studies. Hence, instead of employing Probit Regression, we have used the Instrument Variable Probit Regression methodology in the study to tackle the issue of endogeneity.

IV-probit suits those probit models in which one or more of the regressorare determined endogenously. This is used when you consider that the error term is associated with one or more of the regressor. The estimator of minimum chisquared is invoked with the option two-step (Newey, 1987). It relies on the assumption of the continuous endogenous regressors and unsuitable to use with endogenous regressors which are discrete. The model used in IV probit estimation is:

$$
\begin{aligned}
& \mathrm{yli}^{\mathrm{i}}={ }_{\mathrm{y} 2 \mathrm{i}} \gamma+{ }_{\mathrm{xIi}} \delta+\mu_{\mathrm{i}} \\
& \mathrm{y} 2 \mathrm{i}={ }_{\mathrm{XIi}} \Phi_{\mathrm{I}}+{ }_{\mathrm{x} 2 \mathrm{i}} \Phi_{2}+v_{\mathrm{i}}
\end{aligned}
$$

Where $i=I, \ldots, N, y_{2 i}$ is a $I \times_{n}$ vector of endogenous variables, $x_{1 i}$ is a $I \times_{m I}$ vector of exogenous variables, $x_{2 i}$ is a $\mathrm{I} \times \mathrm{m}_{2}$ vector of additional instruments, and the $\mathrm{y}_{2 \mathrm{i}}$ is reduced form of the equation.

For a typical Probit model, it is presumed that the error term has one variance. However, we presume that $\left(\mu_{\mathrm{i}}, v_{\mathrm{i}}\right)$ is multivariate normal with a matrix of covariance, in the case of a Probit model with an endogenous regressor. Consequently, $\gamma$ and $\delta$ results would not be yielded by the estimator of Newey and two-step estimators of probit. Instead, $\gamma / \sigma$ and $\delta / \sigma$ estimates are generated, where $\sigma$ is defined as the square root of $\operatorname{Var}\left(\mu_{\mathrm{i}} \mid v_{\mathrm{i}}\right)$. Therefore a direct comparison of the estimates obtained from estimator of Newey with those obtained from probit or maximum likelihood is not possible. However, the two-step estimator is still beneficial. The maximum likelihood estimator can struggle to converge, particularly with multiple endogenous variables; but the convergence of the two-step estimator is most definite. Furthermore, while the coefficients from the two models are not comparable precisely; it is still possible to use the two-step calculations to check for statistically significant relations. In two-step IV probit estimation, Wald test of the null hypothesis $\mathrm{H}_{0}$ (of no endogeneity) works as the exogeneity test.

\subsection{Robustness Test}

Weak IV identification test has been conducted to check that the weak-IV concern is not present in the instruments. The weak IV test of STATA module is performed on the endogenous variable(s) in an instrumental variables (IV) model to verify the validity of the instrument used, and create confidence sets for these coefficients. These confidences and tests are robust to weak instruments, in the context that the coefficients are not believed to be known. Weak IV test can be used to estimate linear models (including fixed panel effects and dynamic panel data), probit, and Tobit IV (Finlay, Magnusson, \& Schaffer, 2014). In the case of IV probit, the two-step estimator (Newey's, 1987) is required.

The weak IV test for IV probit in stata reports the Anderson-Rubin test (AR). AR test is a joint test of the structural parameter (beta $=\mathrm{b0}$, which represents the coefficient of endogenous regressor) and the exogeneity of the instruments ( $E$ $(\mathrm{Zu})=0$, where $\mathrm{u}$ indicate the disturbance in the structural equation and $\mathrm{Z}$ indicate the instruments).

\section{Empirical Analysis and Results}

\section{I Stationary Test and Correlation Matrix}

Fisher-type (Choi, 200I) for an unbalanced panel is applied to all variables used in the models to check for stationarity. The study found that a majority of the variables is commonly stationary at their first difference. Out of 4I variables, 39 variables were found stationery at their first difference.

Appendix C, D, E, and F exhibit of correlation among the significant variables of the models. There is a weak correlation reported between the majorities of variables.

\subsection{Results of IV Probit Regression and Interpretation}

Table 3 reports the findings of IV- Probit model I results. The paper has estimated three equations for model Iwith Payment_Cash as the dependent variable. The probit model estimates involve reverse causality and possible biases, which raises concerns of endogeneity. To mitigate this concern for endogeneity, two-step Instrumented Variable (IV) probit regressions (Newey, 1987; Rivers \& Vuong, 1988) has been employed. Specifically, in the first stage, the paper has estimated the current market cap as the selected instrument. In the second stage, using the predicted values of relative current market cap and other variables as regressors, the study estimates the IV probit regression. The second stage results of the IV-probit model, provided in table 3 columns 2, 4, and 6, indicate that the current market cap is negative and significant at the level of $<$ I percent. As can be observed from table 3, net income has a positive and statistically significant relationship with payment dummy for all the three reported models, indicating that if payment for the deal is made in cash then synergy realized in the form of net income is more in the post-acquisition stage. Similar positive and statistically significant outcomes have also been observed for R\&D expense to Net sales in our model, indicating spillover of technology in the post-merger period. Significant results have also been obtained for the leverage variables like Net debt (EQ 3 ) and Net Debt to Ffcf (EQ I \& 2), indicating fewer borrowings for the merged firm. Thus, the results of the empirical analysis of the study support hypothesis I, which states "When payment is made in cash, more synergies are generated". Prob> chi2-is the probability of achieving this chi-square statistic if collectively independent variables do not influence the dependent variable (UCLA: Statistical Consulting Group). This p-value is compared to a critical value, i.e. at I0 percent, 5 percent, and I percent to determine the statistical significance of the overall model. In this case, all the three models are 
statistically significant at less than I percent level. A Wald test of the exogeneity of the instrumented variables is reported at the bottom of the results. On that basis, we refute the null hypothesis that there is no endogeneity.

Table 3. Results of Instrument Variable IV Probit estimation for Mode of Payment in Cashis the dependent variable. This table reports the coefficient estimates and p-statistics from Instrument Variable Probit MODEL I.

\begin{tabular}{|c|c|c|c|c|c|c|}
\hline & EQ I & & EQ 2 & & EQ 3 & \\
\hline & $\begin{array}{l}\text { First stage } \\
\text { (I) }\end{array}$ & $\begin{array}{l}\text { Two-step probit } \\
\text { with endogenous } \\
\text { regressors }(2)\end{array}$ & $\begin{array}{l}\text { First stage } \\
\text { (3) }\end{array}$ & $\begin{array}{l}\text { Two-step probit } \\
\text { with endogenous } \\
\text { regressors }(4)\end{array}$ & First stage(5) & $\begin{array}{l}\text { Two-step probit } \\
\text { with endogenous } \\
\text { regressors }(6)\end{array}$ \\
\hline Cur_Mkt_Cap & & $\begin{array}{l}-1.9114 \\
(0.7866)^{2}\end{array}$ & & $\begin{array}{l}-1.8289 \\
(0.5748)^{2}\end{array}$ & & $\begin{array}{l}-1.4760 \\
(0.4863)^{2}\end{array}$ \\
\hline Net_Income & $\begin{array}{l}6.4955 \\
(0.570)\end{array}$ & $\begin{array}{l}\text { II.6607 } \\
(5.5305)\end{array}$ & $\begin{array}{l}6.6359 \\
(0.627)\end{array}$ & $\begin{array}{l}\text { I I.I299 } \\
(4.2499)\end{array}$ & $\begin{array}{l}7.679 \\
(0.62) \\
\end{array}$ & $\begin{array}{l}\text { I0.4I52 } \\
(4.1947) \\
\text { sty }\end{array}$ \\
\hline $\begin{array}{l}\text { Personnel_Expn_ } \\
\text { Per_Employee }\end{array}$ & & & $\begin{array}{l}-\mathrm{I} .68 \mathrm{E}- \\
09(3.69 \mathrm{E}- \\
09)\end{array}$ & $\begin{array}{l}\text { - I.54E-08 } \\
(1.63 \mathrm{E}-08)\end{array}$ & & \\
\hline $\begin{array}{l}\text { Net_Debt_To_F } \\
\text { fcf }\end{array}$ & $\begin{array}{l}-0.00003 \\
(0.000 \mathrm{I})\end{array}$ & $\begin{array}{l}-0.0011 \\
(0.0016)\end{array}$ & $\begin{array}{l}-0.0002 \\
(0.0003)\end{array}$ & $\begin{array}{l}-0.0037 \\
(0.00233)^{*}\end{array}$ & & \\
\hline Risk_Premium & $\begin{array}{l}-0.0208 \\
(0.020)\end{array}$ & $\begin{array}{l}-0.1561 \\
(0.0499)^{-1}\end{array}$ & $\begin{array}{l}-0.0165 \\
(0.023)\end{array}$ & $\begin{array}{l}-0.1383 \\
(0.0499)^{2}\end{array}$ & $\begin{array}{l}-0.00565 \\
(0.0198)\end{array}$ & $\begin{array}{l}-0.1157 \\
(0.03873)^{(x+1}\end{array}$ \\
\hline Opcfroa_Healy & $\begin{array}{l}-0.0028 \\
(0.004) \\
\end{array}$ & $\begin{array}{l}-0.0708 \\
(0.0304)^{\ldots}\end{array}$ & $\begin{array}{l}-0.0028 \\
(0.009) \\
\end{array}$ & $\begin{array}{l}-0.08294 \\
(0.0364)^{x}\end{array}$ & $\begin{array}{l}-0.00372 \\
(0.0083)\end{array}$ & $\begin{array}{l}-0.0534 \\
(0.029 \mathrm{I})^{*}\end{array}$ \\
\hline $\begin{array}{l}\text { Rd_Expend_To_ } \\
\text { Net_Sales }\end{array}$ & $\begin{array}{l}0.1342 \\
(0.037)\end{array}$ & $\begin{array}{l}0.2185 \\
(0.1277)\end{array}$ & $\begin{array}{l}0.1316 \\
(0.039)\end{array}$ & $\begin{array}{l}0.2012 \\
(0.1040)\end{array}$ & $\begin{array}{l}\text { 0.I I93 } \\
(0.03748)^{\text {and }}\end{array}$ & $\begin{array}{l}0.1801 \\
(0.0876)\end{array}$ \\
\hline Net_Debt & & & & & $\begin{array}{l}-1.2330 \\
(0.16332)^{x+x+x}\end{array}$ & $\begin{array}{l}-1.2993 \\
(0.6302)\end{array}$ \\
\hline Goodwill_Assets & & & & & $\begin{array}{l}0.016086 \\
(0.0032)^{2}\end{array}$ & $\begin{array}{l}0.0276 \\
(0.0098) \\
\end{array}$ \\
\hline constant & $\begin{array}{l}0.4326 \\
(0.127)\end{array}$ & $\begin{array}{l}1.3274 \\
(0.5524)\end{array}$ & $\begin{array}{l}0.3159 \\
(0.148)\end{array}$ & $\begin{array}{l}1.3175 \\
(0.445)\end{array}$ & & $\begin{array}{l}\text { I.1969 } \\
(0.4517)\end{array}$ \\
\hline $\begin{array}{l}\text { Wald test of } \\
\text { exogeneity }\end{array}$ & & $16.78^{\prime}$ & & 22.07 & & $14.60^{2}$ \\
\hline $\begin{array}{l}\text { Anderson-Rubin } \\
\text { test }\end{array}$ & & $17.82^{2}$ & & 26.47 & & I8.II \\
\hline Wald chi2(9) & & 17.95 & & 23.02 & & 23.59 \\
\hline Prob > chi2 & 0 & 0.0064 & 0 & 0.0017 & 0 & 0.0027 \\
\hline Number of obs & 660 & 660 & 529 & 529 & 577 & 577 \\
\hline
\end{tabular}

Table 4 presents the findings of IV-Probit for model 2 "When payment is made in cash, bidder liquidity is high". Probit regression model has been run with Payment_Cash as the dependent variable and liquidity variables such as free cash flow and operating cash flow return on assets along with other variables as part of the independent variables. This model estimate Net Assets as the selected instrument in all three reported equations. As per the results Operating cash flow return on asset, Working Capital, Cash and Cash Equivalent and Quick ratio are statistically significant but negative in all the three models when the payment is made in cash. This indicates that the combined firm has lower liquidity for Indian Mergers \& Acquisitions, and it is more likely the company will struggle with paying debts when payment is made in cash, thereby negating the hypothesis 2 . However, free cash flow was found to have an opposite effect in our estimation. Prob> chi2 indicates that the EQ I and 2 are statistically significant at less than IO percent level and EQ 3 at less than 5 percent level. Based on Wald's test of the exogeneity of the instrumented variables, we refute the null hypothesis of no endogeneity. 
Table 4. Results of Instrument Variable Probit estimation for Mode of Payment in Cash as the dependent variable. This table reports the estimates of coefficient and p-statistics from Instrument Variable Probit Model 2.

\begin{tabular}{|c|c|c|c|c|c|c|}
\hline & EQ I & & EQ 2 & & EQ 3 & \\
\hline & $\begin{array}{l}\text { First stage } \\
\text { (I) }\end{array}$ & $\begin{array}{l}\text { Two-step } \\
\text { probit with } \\
\text { endogenous } \\
\text { regressors (2) }\end{array}$ & $\begin{array}{l}\text { First stage } \\
\text { (3) }\end{array}$ & $\begin{array}{l}\text { Two-step } \\
\text { probit with } \\
\text { endogenous } \\
\text { regressors (4) }\end{array}$ & $\begin{array}{l}\text { First } \\
\text { stage(5) }\end{array}$ & $\begin{array}{l}\text { Two-step } \\
\text { probit with } \\
\text { endogenous } \\
\text { regressors (6) }\end{array}$ \\
\hline Net_Assets & & $\begin{array}{l}22.553 \\
(8.457)\end{array}$ & & $\begin{array}{l}19.506 \\
(8.604)\end{array}$ & & $\begin{array}{l}20.024 \\
(8.849)\end{array}$ \\
\hline Working_Capital & $\begin{array}{l}0.367 \\
(0.046)^{2}\end{array}$ & $\begin{array}{l}-9.05 \mathrm{I} \\
(3.435)\end{array}$ & $\begin{array}{l}0.519 \\
(0.061)\end{array}$ & $\begin{array}{l}-10.739 \\
(4.778)\end{array}$ & $\begin{array}{l}0.527 \\
(0.062)\end{array}$ & $\begin{array}{l}-10.876 \\
(4.987)\end{array}$ \\
\hline Cf_Free_Cash_Flow & $\begin{array}{l}-0.079 \\
(0.090)\end{array}$ & $\begin{array}{l}2.315 \\
(2.395)\end{array}$ & $\begin{array}{l}-0.289 \\
(0.122)\end{array}$ & $\begin{array}{l}6.01 \\
(3.505)\end{array}$ & $\begin{array}{l}-0.280 \\
(0.122)\end{array}$ & $\begin{array}{l}6.338 \\
(3.554)\end{array}$ \\
\hline Opcfroa_Healy & $\begin{array}{l}0.001 \\
(0.0004)\end{array}$ & $\begin{array}{l}-0.060 \\
(0.0269)\end{array}$ & $\begin{array}{l}-0.00005 \\
(0.0007)\end{array}$ & $\begin{array}{l}-0.052 \\
(0.028)\end{array}$ & $\begin{array}{l}-0.00005 \\
(0.001)\end{array}$ & $\begin{array}{l}-0.0464 \\
(0.0274)\end{array}$ \\
\hline Invent_Turn & $\begin{array}{l}0.0001 \\
(0.0001)\end{array}$ & $\begin{array}{l}-0.018 \\
(0.017)\end{array}$ & $\begin{array}{l}0.0004 \\
(0.0002)\end{array}$ & $\begin{array}{l}-0.019 \\
(0.014)\end{array}$ & $\begin{array}{l}0.0004 \\
(0.00015)\end{array}$ & $\begin{array}{l}-0.02 \mathrm{II} 4 \\
(0.01525)\end{array}$ \\
\hline Cce_And_Sti_Detailed & $\begin{array}{l}0.034 \\
(0.0173)^{2}\end{array}$ & $\begin{array}{l}-1.347 \\
(0.657)\end{array}$ & $\begin{array}{l}0.0254 \\
(0.0235)\end{array}$ & $\begin{array}{l}-1.002 \\
(0.649)\end{array}$ & $\begin{array}{l}0.0262 \\
(0.0235)\end{array}$ & $\begin{array}{l}-0.953 \\
(0.6674)\end{array}$ \\
\hline Quick_Ratio & $\begin{array}{l}0.0149 \\
(0.0047)\end{array}$ & $\begin{array}{l}-0.604 \\
(0.232)\end{array}$ & $\begin{array}{l}0.0191 \\
(0.0064)^{x}\end{array}$ & $\begin{array}{l}-0.634 \\
(0.262)\end{array}$ & $\begin{array}{l}0.0192 \\
(0.0064)\end{array}$ & $\begin{array}{l}-0.585 \\
(0.2709)\end{array}$ \\
\hline Ebitda & $\begin{array}{l}0.396 \\
(0.1005)\end{array}$ & $\begin{array}{l}-8.2799 \\
(3.5739)\end{array}$ & $\begin{array}{l}0.7466 \\
(0.1349)^{x}\end{array}$ & $\begin{array}{l}-13.72 \\
(6.179)\end{array}$ & $\begin{array}{l}0.7493 \\
(0.135)\end{array}$ & $\begin{array}{l}-12.83 \\
(6.377)\end{array}$ \\
\hline $\begin{array}{l}\text { Revenue_Sequential_Gro } \\
\text { wth }\end{array}$ & $\begin{array}{l}\text { I.I7E- } \\
06(3.83 \mathrm{E}- \\
06) \\
\end{array}$ & $\begin{array}{l}-0.0013 \\
(0.0017)\end{array}$ & $\begin{array}{l}3.55 \mathrm{E}- \\
07(5.2 \mathrm{IE}- \\
06)\end{array}$ & $\begin{array}{l}-0.0013 \\
(0.0017)\end{array}$ & $\begin{array}{l}0.0000004 \\
(0.000005)\end{array}$ & $\begin{array}{l}-0.0017 \\
(0.0017)\end{array}$ \\
\hline $\begin{array}{l}\text { Net_Fixed_Assets_5_Ye } \\
\text { ar_Growth }\end{array}$ & $\begin{array}{l}- \\
0.00004(0 \\
.00008)\end{array}$ & $\begin{array}{l}-0.0014 \\
(0.0023)\end{array}$ & $\begin{array}{l}0.000 \mathrm{I}(0 . \\
0001 \mathrm{I})\end{array}$ & $\begin{array}{l}-0.0041 \\
(0.0027)\end{array}$ & $\begin{array}{l}0.000093 \\
(0.00014)\end{array}$ & $\begin{array}{l}-0.00423 \\
(0.0028)\end{array}$ \\
\hline Cash_Flow_To_Net_Inc & $\begin{array}{l}0.0026 \\
(0.0004)\end{array}$ & $\begin{array}{l}-0.075 \\
(0.025)\end{array}$ & $\begin{array}{l}0.0058 \\
(0.0005)^{x+x}\end{array}$ & $\begin{array}{l}-0.129 \\
(0.0522)\end{array}$ & $\begin{array}{l}0.0058 \\
(0.0005)\end{array}$ & $\begin{array}{l}-0.132 \\
(0.0536)\end{array}$ \\
\hline $\begin{array}{l}\text { Total_Debt_And_Prefer } \\
\text { red_Equity }\end{array}$ & $\begin{array}{l}-0.524 \\
(0.0419)^{4}\end{array}$ & $\begin{array}{l}12.560 \\
(4.517)\end{array}$ & $\begin{array}{l}-0.169 \\
(0.0525)^{x+2 x}\end{array}$ & $\begin{array}{l}4.343 \\
(1.8002)\end{array}$ & $\begin{array}{l}-0.1725 \\
(0.0527) \\
\end{array}$ & $\begin{array}{l}4.128 \\
(1.877)\end{array}$ \\
\hline Capitalization_Ratio & $\begin{array}{l}0.00075(0 \\
.0003)^{2 x+x}\end{array}$ & $\begin{array}{l}-0.016 \\
(0.0107)\end{array}$ & $\begin{array}{l}-0.00107 \\
(0.0004)^{4}\end{array}$ & $\begin{array}{l}0.0212 \\
(0.0117)\end{array}$ & $\begin{array}{l}-0.0011 \\
(0.0004)\end{array}$ & $\begin{array}{l}0.02 \mathrm{I} 4 \\
(0.012 \mathrm{I})\end{array}$ \\
\hline Cons & & $\begin{array}{l}5.235 \\
(2.385 \mathrm{I})^{\text {kxyx }}\end{array}$ & & $\begin{array}{l}-6.994 \\
(2.991)\end{array}$ & $\begin{array}{l}0.3828 \\
(0.034)\end{array}$ & $\begin{array}{l}-7.148 \\
(3.073)\end{array}$ \\
\hline Wald test of exogeneity & & $36.08^{x}$ & & $33.58^{2 x}$ & & $34.16^{x+x}$ \\
\hline Anderson-Rubin test & & $32.2 I^{x}$ & & $31.63^{2 x+x}$ & & $32.28^{x+x}$ \\
\hline Wald chi2(9) & & 23.07 & & I9.8I & & 25.80 \\
\hline Prob> chi2 & 0 & $0.059 \mathrm{I}$ & 0 & 0.0999 & 0 & 0.0275 \\
\hline Number of obs & 577 & 577 & 577 & 577 & 577 & 577 \\
\hline
\end{tabular}


Table 5 reports the findings of IV probit regression model run for the Model 3 with Industry relatedness as the dependent variable. This model estimates the current market cap as the selected instrument. The second stage results of the IV-probit model, presented in columns 2 and 6 of Table 5, reflects that the instrumented current market cap is negative and significant at the less than I percent level and less than I0 percent level in EQ 3 (column 4). It has been highlighted by the results that significant variables like Return on capital, Net income growth, total operating expense as a percentage of sales, asset turnover, and free Cash flow yield have a positive and statistically significant relationship with the relatedness of the industry of the reported EQ 2 and 3, indicating that if acquirer undertakes a horizontal merger then synergy in the form of said variables are gained post the merger. Similar positive and statistically significant results have also been observed for Inventory turnover in all the reported models. Thus, the results of the study's empirical analysis do support hypothesis 3 , which states "When mergers \& acquisition take place in the related industry sector, more synergies are generated". However, Financial Leverage and Net debt of the combined firm were observed to have a positive and statistically significant relationship with the relatedness of the industry as depicted in EQ I; indicating an increase in borrowing post-merger for the combined firm. The rise in financial leverage is the result of an increase in debt capacity (Ghosh \& Jain, 2000). Prob $>$ chi2 indicates that all the models are statistically significant at less than I percent level. We refute the null hypothesis of no endogeneity, based on Wald's test.

Table 5. Results of Instrument Variable Probit estimation for Relatedness of Industry as the dependent variable. This table reports the estimates of the coefficient and p-statistics from Instrument Variable Probit MODEL 3.

\begin{tabular}{|c|c|c|c|c|c|c|}
\hline & EQ I & & EQ 2 & & EQ3 & \\
\hline & $\begin{array}{l}\text { First stage } \\
\text { (I) }\end{array}$ & $\begin{array}{l}\text { Two-step } \\
\text { probit with } \\
\text { endogenous } \\
\text { regressors (2) }\end{array}$ & $\begin{array}{l}\text { First stage } \\
\text { (3) }\end{array}$ & $\begin{array}{l}\text { Two-step } \\
\text { probit with } \\
\text { endogenous } \\
\text { regressors (4) }\end{array}$ & $\begin{array}{l}\text { First } \\
\text { stage } \\
(5)\end{array}$ & $\begin{array}{l}\text { Two-step probit } \\
\text { with endogenous } \\
\text { regressors }(6)\end{array}$ \\
\hline Cur_Mkt_Cap & & $\begin{array}{l}0.2758 \\
(0.106)\end{array}$ & & $\begin{array}{l}1.636 \\
(0.905)\end{array}$ & & $\begin{array}{l}0.368 \\
(0.126)\end{array}$ \\
\hline Invent_Turn & $\begin{array}{l}0.0033 \\
(0.0008)\end{array}$ & $\begin{array}{l}0.0025 \\
(0.0019)\end{array}$ & $\begin{array}{l}0.001 \\
(0.0006)\end{array}$ & $\begin{array}{l}0.006 \\
(0.004)\end{array}$ & $\begin{array}{l}0.00 \mathrm{I} \\
(0.00 \mathrm{I})\end{array}$ & $\begin{array}{l}0.0069 \\
(0.0032)\end{array}$ \\
\hline Ebitda_To_Revenue & $\begin{array}{l}-0.0009 \\
(0.0007)\end{array}$ & $\begin{array}{l}0.0179 \\
(0.004)\end{array}$ & & & $\begin{array}{l}-0.0035 \\
(0.0025)\end{array}$ & $\begin{array}{l}0.0253 \\
(0.0129)\end{array}$ \\
\hline Oper_Margin & $\begin{array}{l}-0.0023 \\
(0.0015)^{* x}\end{array}$ & $\begin{array}{l}-0.0176 \\
(0.0042)\end{array}$ & & & & \\
\hline $\begin{array}{l}\text { Total_Opex_As_A_Perc } \\
\text { entage_Sales }\end{array}$ & $\begin{array}{l}-0.0043 \\
(0.0014)^{\text {xaxt }}\end{array}$ & $\begin{array}{l}-0.0049 \\
(0.0027)\end{array}$ & $\begin{array}{l}-0.00304 \\
(0.00098)^{x+y+x}\end{array}$ & $\begin{array}{l}-0.0115 \\
(0.0045)\end{array}$ & $\begin{array}{l}-0.0049 \\
16)^{(0.00}\end{array}$ & $\begin{array}{l}-0.0196 \\
(0.0078)\end{array}$ \\
\hline Quick_Ratio & $\begin{array}{l}0.0447 \\
(0.0306)\end{array}$ & $\begin{array}{l}-0.125 \\
(0.0459)\end{array}$ & $\begin{array}{r}-0.0463 \\
)^{(0.02039}\end{array}$ & $\begin{array}{l}-0.0143 \\
(0.0657)\end{array}$ & $\begin{array}{l}0.0234 \\
(0.0313)\end{array}$ & $\begin{array}{l}-0.047 \\
(0.0465)\end{array}$ \\
\hline Return_Com_Eqy & $\begin{array}{l}0.0007 \\
(0.0012)\end{array}$ & $\begin{array}{l}-0.0144 \\
(0.0031)\end{array}$ & & & & \\
\hline Asset_Turnover & $\begin{array}{l}0.0292 \\
(0.0905)\end{array}$ & $\begin{array}{l}0.2066 \\
(0.125)\end{array}$ & $\begin{array}{l}-0.1164 \\
(0.0604)\end{array}$ & $\begin{array}{l}0.6911 \\
(0.2234)\end{array}$ & $\begin{array}{l}-0.205 \\
(0.098)\end{array}$ & $\begin{array}{l}0.3964 \\
(0.154)\end{array}$ \\
\hline Free_Cash_Flow_Yield & $\begin{array}{l}-0.00 I 4 \\
(0.0005)^{\ldots x+x}\end{array}$ & $\begin{array}{l}0.0052 \\
(0.0015)\end{array}$ & $\begin{array}{l}-0.000 I \text { I } \\
(0.00035)\end{array}$ & $\begin{array}{l}0.002733 \\
(0.00142)\end{array}$ & $\begin{array}{l}-0.0013 \\
(0.00057 \\
)\end{array}$ & $\begin{array}{l}0.00163 \\
(0.00125)\end{array}$ \\
\hline Ebitda & & & $\begin{array}{l}-\mathrm{I} .724 \\
(\mathrm{I} .2352)\end{array}$ & $\begin{array}{l}-2.4798 \\
(2.0043 \mathrm{I}) \\
\end{array}$ & & \\
\hline Fncl_Lvrg & & & 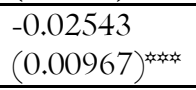 & $\begin{array}{l}0.019 \mathrm{I} \\
(0.033 \mathrm{I}) \\
\end{array}$ & & \\
\hline Capitalization_Ratio & & & $\begin{array}{l}-0.00595 \\
(0.0012) \\
\end{array}$ & $\begin{array}{l}0.0143 \\
(0.00665)^{x}\end{array}$ & & \\
\hline Bs_Long_Term_Investm & & & 0.33778 & $-\mathrm{I} .055 \mathrm{I}$ & & \\
\hline
\end{tabular}




\begin{tabular}{|c|c|c|c|c|c|c|}
\hline ents & & & $(0.16034)^{2 x+x}$ & $(0.5077)$ & & \\
\hline Ebitda_To_Revenue & & & $\begin{array}{l}-0.0000 \mathrm{I} 4 \\
(0.00060)\end{array}$ & $\begin{array}{l}0.0489 \\
(0.01196)^{13 x+x}\end{array}$ & & \\
\hline Return_On_Cap & & & $\begin{array}{l}0.00473 \\
(0.00240)^{2}\end{array}$ & $\begin{array}{l}-0.0211 \\
(0.00780)^{x y x}\end{array}$ & $\begin{array}{l}0.0192 \\
(0.004)\end{array}$ & $\begin{array}{l}-0.0219 \\
(0.0066)\end{array}$ \\
\hline Tobin_Q_Ratio & & & $\begin{array}{l}0.83 I 5 \\
(0.0288)\end{array}$ & $\begin{array}{l}-\mathrm{I} .4 \mathrm{I} 32 \\
(0.7662)\end{array}$ & & \\
\hline $\begin{array}{l}\text { Normalized_Net_Incom } \\
\text { e_Growth }\end{array}$ & & & $\begin{array}{l}- \\
0.000038(0 . \\
00002)^{*}\end{array}$ & $\begin{array}{l}0.00025 \\
(8.27 \mathrm{E}-05)\end{array}$ & $\begin{array}{l}-0.00003 \\
(0.00004 \\
)\end{array}$ & $\begin{array}{l}0.00022 \\
(0.00007)\end{array}$ \\
\hline Oper_Margin & & & $\begin{array}{l}-0.00445 \\
(0.0011)\end{array}$ & $\begin{array}{l}-0.043 \\
(0.0109 \mathrm{I})\end{array}$ & $\begin{array}{l}-0.0005 \\
(0.002)\end{array}$ & $\begin{array}{l}-0.041 \\
(0.01186)\end{array}$ \\
\hline Net_Debt & & & & & $\begin{array}{l}0.0453 \\
(0.229)\end{array}$ & $\begin{array}{l}0.9648 \\
(0.338)\end{array}$ \\
\hline $\begin{array}{l}\text { Net_Fixed_Assets_5_Ye } \\
\text { ar_Growth }\end{array}$ & & & & & $\begin{array}{l}-0.0001 \\
(0.0005)\end{array}$ & $\begin{array}{l}0.00742 \\
(0.0023)\end{array}$ \\
\hline Mkt_Cap_To_Revenue & & & & & $\begin{array}{l}0.0098 \\
(0.007) \\
\end{array}$ & $\begin{array}{l}-0.0232 \\
(0.0134)^{4 x}\end{array}$ \\
\hline Constant & $\begin{array}{l}0.6927 \\
(0.181)\end{array}$ & $\begin{array}{l}0.758 \\
(0.318)\end{array}$ & $\begin{array}{l}0.263 \\
(0.1303)\end{array}$ & $\begin{array}{l}1.275 \\
(0.466)\end{array}$ & $\begin{array}{l}0.659 \\
(0.212)\end{array}$ & $\begin{array}{l}\mathrm{I} .42 \mathrm{I} 6 \\
(0.855 \mathrm{I})\end{array}$ \\
\hline Wald test of exogeneity & & $8.43^{\text {thy }}$ & & $5.5 I^{\text {新 }}$ & & II.00 \\
\hline Anderson-Rubin test & & $7.10^{\text {taxt }}$ & & 5.20 & & $9.16^{2 x}$ \\
\hline Wald chi2(9) & & 44.50 & & 40.97 & & 51.77 \\
\hline Prob> chi 2 & 0 & 0.0000 & 0 & 0.0003 & 0 & 0.0000 \\
\hline Number of obs & 744 & 744 & 725 & 725 & 578 & 578 \\
\hline
\end{tabular}

Lastly, IV Probit model has been estimated for model 4 " When payment is made in equity, bidder leverage is high", for which results are presented in table 6. Payment_Equity is the dependent variable and leverage variables along with other variables form the part of the independent variables. The current market cap is the selected instrument in EQ I and 2, along with other variables in the outcome regression in the first stage. For the estimation of EQ 3, the total asset has been used as the selected instrument. As per the results, EQ I suggests long term borrowing to have a statistically significant relationship with payment equity. EQ 2 suggests short and long term debt and EQ 3 suggests net debt to have a negative and statistically significant relationship with the payment equity. This suggests lower borrowings post the merger when the payment is made in equity, thus not supporting our hypothesis 4 . Prob>chi2indicates that all the models are statistically significant at less than I percent level. We reject the null hypothesis of no endogeneity, based on Wald's test.

Table 6. Results of Instrument Variable Probit estimation for Mode of Payment in Equity as the dependent variable. This table reports the estimates of the coefficient and p-statistics from Instrument Variable Probit MODEL 4.

\begin{tabular}{|c|c|c|c|c|c|c|}
\hline & EQ I & & EQ 2 & & EQ 3 & \\
\hline & $\begin{array}{l}\text { First stage } \\
\text { (I) }\end{array}$ & $\begin{array}{l}\text { Two-step } \\
\text { probit with } \\
\text { endogenous } \\
\text { regressors (2) }\end{array}$ & First stage (3) & $\begin{array}{l}\text { Two-step } \\
\text { probit with } \\
\text { endogenous } \\
\text { regressors (4) }\end{array}$ & First stage(5) & $\begin{array}{l}\text { Two-step probit with } \\
\text { endogenous } \\
\text { regressors (6) }\end{array}$ \\
\hline Cur_Mkt_Cap & & $\begin{array}{l}\text { I.33 } \\
(0.67) \\
\end{array}$ & & $\begin{array}{l}\text { I.I69 } \\
(0.467) \\
\end{array}$ & & \\
\hline Bs_Lt_Borrow & $\begin{array}{l}0.318 \\
(0.283)\end{array}$ & $\begin{array}{l}-1.985 \\
(0.5 \mathrm{I}) \\
\end{array}$ & & & & \\
\hline Net_Debt_To_Ffcf & -0.00001 & 0.003 & & & & \\
\hline
\end{tabular}




\begin{tabular}{|c|c|c|c|c|c|c|}
\hline & $(0.00006)$ & $(0.002 \mathrm{I})$ & & & & \\
\hline Tot_Debt_To_Tot_Asset & $\begin{array}{l}-0.014 \\
(0.0024)\end{array}$ & $\begin{array}{l}0.02 \\
(0.0104)\end{array}$ & & & & \\
\hline Free_Cash_Flow_Yield & $\begin{array}{l}-0.0014 \\
(0.0006)\end{array}$ & $\begin{array}{l}0.004 \\
(0.0014)\end{array}$ & & & & \\
\hline Net_Income & $\begin{array}{l}6.667 \\
(0.572)\end{array}$ & $\begin{array}{l}-8.3663 \\
(4.7636)\end{array}$ & & & & \\
\hline Quick_Ratio & $\begin{array}{l}-0.0733 \\
(0.03099)\end{array}$ & $\begin{array}{l}0.347 \\
(0.112)\end{array}$ & & & & \\
\hline $\begin{array}{l}\text { Short_And_Long_Term_ } \\
\text { Debt }\end{array}$ & & & $\begin{array}{l}2.284 \\
(0.32442)^{2}\end{array}$ & $\begin{array}{l}-5.126 \\
(\mathrm{I} .628)\end{array}$ & & \\
\hline $\begin{array}{l}\text { Total_Debt_And_Preferre } \\
\text { d_Equity }\end{array}$ & & & $\begin{array}{l}-3.004 \\
(0.354)\end{array}$ & $\begin{array}{l}4.935 \\
(1.838)\end{array}$ & & \\
\hline Is_Oper_Inc & & & $\begin{array}{l}7.534 \\
(\mathrm{I} .653)\end{array}$ & $\begin{array}{l}-\mathrm{I} 2.648 \\
(4.10 \mathrm{I})\end{array}$ & & \\
\hline Ebitda & & & $\begin{array}{l}-\mathrm{I} .652 \\
(\mathrm{I} .55 \mathrm{I})\end{array}$ & $\begin{array}{l}5.391 \\
(2.5356)\end{array}$ & & \\
\hline $\begin{array}{l}\text { Rd_Expend_To_Net_Sal } \\
\text { es }\end{array}$ & & & $\begin{array}{l}0.1308 \\
(0.03553)\end{array}$ & $\begin{array}{l}-0.15 \mathrm{I} 42 \\
(0.08326)\end{array}$ & & \\
\hline Bs_Tot_Asset & & & & & & $\begin{array}{l}3.2273 \\
(0.976)\end{array}$ \\
\hline Net_Debt & & & & & $\begin{array}{l}0.505 \\
(0.033)\end{array}$ & $\begin{array}{l}-2.166 \\
(0.563)\end{array}$ \\
\hline $\begin{array}{l}\text { Degree_Financial_Leverag } \\
\text { e }\end{array}$ & & & & & $\begin{array}{l}0.000 I 4 \\
(0.00025)\end{array}$ & $\begin{array}{l}-0.004 \\
(0.0025)\end{array}$ \\
\hline Totaldebttototalequity & & & & & $\begin{array}{l}\text { I.00E- } \\
06(1.61 E- \\
06)\end{array}$ & $\begin{array}{l}\text { I.42E-05 } \\
(1.63 \mathrm{E}-05)\end{array}$ \\
\hline Gross_Fix_Asset_Turn & & & & & $\begin{array}{l}0.00052 \\
(0.00216)\end{array}$ & $\begin{array}{l}0.0702 \\
(0.0309)\end{array}$ \\
\hline Cf_Free_Cash_Flow & & & & & $\begin{array}{l}0.0939 \\
(0.0652)\end{array}$ & $\begin{array}{l}-0.818 \\
(0.464)\end{array}$ \\
\hline Pretax_Margin & & & & & $\begin{array}{l}0.00004 \\
(0.00015)\end{array}$ & $\begin{array}{l}0.0015 \\
(0.0009 \mathrm{I})\end{array}$ \\
\hline Constant & $\begin{array}{l}1.0775 \\
(0.259)\end{array}$ & $\begin{array}{l}-0.781 \\
(0.9823)\end{array}$ & $\begin{array}{l}0.5242 \\
(0.1062) \\
\end{array}$ & $\begin{array}{l}-0.03086 \\
(0.3362)\end{array}$ & $\begin{array}{l}0.8347 \\
(0.02295)^{2}\end{array}$ & $\begin{array}{l}-2.4354 \\
(0.884 \mathrm{I}) \\
\end{array}$ \\
\hline Wald test of exogeneity & & $7.76^{-2}$ & & $13.40^{2}$ & & $13.74^{\prime}$ \\
\hline Anderson-Rubin test & & 8.09 & & $12.90^{2}$ & & $13.94^{2}$ \\
\hline Wald chi2(9) & & 32.95 & & 28.42 & & 38.70 \\
\hline Prob> chi2 & 0 & $0.000 \mathrm{I}$ & 0 & $0.000 \mathrm{I}$ & 0 & 0.0000 \\
\hline Number of obs & $7 \mathrm{I} 2$ & $7 \mathrm{I} 2$ & 732 & 732 & 795 & 795 \\
\hline
\end{tabular}


Summary of result of hypothesis testing has been detailed below in the table.

Table 7. Summary results of hypothesis testing

\begin{tabular}{|c|c|c|c|}
\hline Objectives & Hypothesis & $\begin{array}{l}\text { Expected } \\
\text { Sign }\end{array}$ & Test Result \\
\hline Model I & $\mathrm{H}_{\mathrm{I}}$ : When payment is made in cash, more synergies are generated. & + & Supported \\
\hline Model 2 & $\mathrm{H}_{2:}$ When bidder liquidity is high, payment is made in cash. & + & $\begin{array}{l}\text { Not } \\
\text { Supported }\end{array}$ \\
\hline Model 3 & $\begin{array}{l}\mathrm{H}_{3} \text { : When merger } \& \text { acquisition take place in the related industry sectors, } \\
\text { more synergies are generated. }\end{array}$ & + & Supported \\
\hline Model 4 & $\mathrm{H}_{4}$ : When bidder leverage is high, payment is made in equity. & + & $\begin{array}{l}\text { Not } \\
\text { Supported }\end{array}$ \\
\hline
\end{tabular}

Thus, this study contributes to the literature in two ways. The main finding of the present study is the generation of synergies if the mode of payment for merger and acquisition is cash for Indian Corporate. Also, horizontal mergers generate greater value for the Indian corporate. The robustness of the results was checked further by estimating the weak IV instrument robustness test as has been discussed in the sub section 5.3 below.

\subsection{Weak Instrument Robustness Test for the Instrument Variable (Weak IV Test)}

The Anderson-Rubin statistics, as reported in Table 3,4,5,6 for each Model specified in the study, are significant at less than I percent significance level. It refutes the null hypothesis, which states that the coefficient is zero on the endogenous variable. To put it another way, the instruments developed are not weak. These findings indicate that the instrument is strongly related to the endogenous variable and does not suffer from the weak IV problem. The weak-instrument-robust inference tests are also significantly varied from zero, suggesting that the predicted effects are robust to weak IV problems if any.

\section{Conclusion}

A firm's financial assets play a significant part in the decision-making phase of a merger. The present paper aims to improve the existing literature on assessing M\&A activity in Indian corporate. This research paper aims primarily to analyze the (a) Synergies realized when the mode of payment in the merger deal is cash, (b) impact on bidder liquidity when payment is made in cash (c) Synergies realized when both target and acquirer in the deal belong to related industry, i.e. the merger is horizontal and (d) assess the impact on bidder leverage when payment is made in equity. A panel of I20 major Indian M\&A deals from 2005 to 2015, each having 3 years of data pre and post-merger (seven years of data in totality including the year of the merger), i.e. data from 2002 to 2018 has been used in the analysis for the considered firms. The study employs Instrument Variable Probit Regression analysis to tackle the issue of endogeneity.

Summary of results for the models employed in the present study has been detailed in the table below.

Table 8. Significant variables and their relationship with the dependent variable as per the present study

\begin{tabular}{|c|c|c|c|}
\hline Objectives & Hypothesis & $\begin{array}{l}\text { Significant variables as per the study } \\
\text { conducted }\end{array}$ & $\begin{array}{l}\text { Relationship with the } \\
\text { dependent variable }\end{array}$ \\
\hline \multirow[t]{2}{*}{ Model I } & \multirow{2}{*}{$\begin{array}{l}\mathrm{H}_{\mathrm{I}} \text { : When payment is made in cash, } \\
\text { more synergies are generated. }\end{array}$} & Net Income & Positive \\
\hline & & R\&D Expenditure To Net Sales & Positive \\
\hline \multirow[t]{4}{*}{ Model 2} & \multirow{4}{*}{$\begin{array}{l}\mathrm{H}_{2:} \text { When bidder liquidity is high, } \\
\text { payment is made in cash. }\end{array}$} & Operating Cash Flow Return On Asset & Negative \\
\hline & & Working Capital & Negative \\
\hline & & Cash And Cash Equivalent & Negative \\
\hline & & Quick Ratio & Negative \\
\hline \multirow[t]{5}{*}{ Model 3} & \multirow{5}{*}{$\begin{array}{l}\mathrm{H}_{3:} \text { When merger } \& \text { acquisition take } \\
\text { place in the related industry sectors, } \\
\text { more synergies are generated. }\end{array}$} & Return On Capital & Positive \\
\hline & & Net Income Growth & Positive \\
\hline & & $\begin{array}{l}\text { Total Operating Expense As A Percentage Of } \\
\text { Sales }\end{array}$ & Positive \\
\hline & & Asset Turnover & Positive \\
\hline & & Free Cash Flow Yield & Positive \\
\hline \multirow[t]{3}{*}{ Model 4} & \multirow{3}{*}{$\begin{array}{l}\mathrm{H}_{4} \text { : When bidder leverage is high, } \\
\text { payment is made in equity. }\end{array}$} & Long Term Borrowing & Negative \\
\hline & & Net Debt & Negative \\
\hline & & Short And Long Term Debt & Negative \\
\hline
\end{tabular}


From the above table 8 , it is indicated that in the case payment method in the deal is cash; M\&A appears to be financially profitable for the bidder companies and synergies are realized for the Indian corporate. The major contribution of the present research is in the identification of the sources of synergy creation for the India M\&A deals. The study highlight that net income has a positive and statistically significant relationship with cash payment of deal. Significant results have also been obtained for the leverage variables like net debt and net debt to free cash flow, indicating fewer borrowing for the merged firm in the post-merger period. Similar positive and statistically significant results have also been observed for $\mathrm{R} \& \mathrm{D}$ expense to net sales in our model, indicating spillover of technology post the merger. These results align with existing research such as Ghosh (200I), Megginson, Morgan, and Nail (2005), Ismail (20II). Secondly, we show that there is a significant association between realization of synergies and similarities of industry of target and acquirer firm. It was found that net income growth, return on capital, total operating expense as a percentage of sales, asset turnover, and free Cash flow yield contributes to the value creation in case of relatedness of industry in the merger deal. Thus, the results of the empirical analysis of the study do support the generation of synergies in the case of horizontal mergers. These results are found to be in resonance with Barai and Mohanty (2014), Rozen-Bakher (2018) but in dissonance with Mooney and Shim (20I5).

The results also suggested an increase in borrowing post-merger for the combined firm. The improvement in financial leverage is the result of the rise in debt capacity (Ghosh \& Jain, 2000). Operating cash flow return on asset, working capital, cash and cash equivalent and quick ratio is statistically significant but negative when the payment is made in cash. This indicates that the combined firm has lower liquidity for Indian Mergers \& Acquisitions, and it is more likely the company will struggle with paying debts when payment is made in cash. This is in contrast with Jensen's theory of free cash flow (Jensen, 1986). Our results also indicate that leverage has a negative relationship with equity mode of payment. It implies the lowering of borrowings post the merger when the payment is made in equity.

\section{I Implications for the Indian Market}

From the results of this analysis can be extracted some significant implications. Firstly, it supports the results of previous research that adhere to the point of view that bidder firms in India have achieved better financial performance post the merger and acquisition. The nature and trend of the Indian companies' mergers \& acquisitions strategies show more horizontal mergers. This lends support to the argument that Indian firms are concentrating on their core areas and growing further into similar strength areas that are helping to realize synergistic benefits. The major contribution of the study lies in determining various sources of value creation or destruction for Indian mergers and acquisitions. It supports the hypothesis that M\&A generates synergy for Indian M\&As when Indian corporate focus on undertaking merger \& acquisitions in similar industries, to gain economies of scale and create value post the merger. Secondly, the decision to use stock or cash often sends signals about the acquirer's estimate of the risk of failing to achieve the synergies anticipated from the acquisition. Repeated empirical research shows that the market responds far more favorably to cash-deal announcements than to stock-deal announcements. Synergy has been shown to be created post the merger in case cash is the preferred mode of payment for the merger deal in Indian scenario. Managers in the merger deal should emphasize on cash payment for the deal to generate higher value creation.

\section{References}

Andrade, G., Mitchell, M., \& Stafford, E. (200I). New evidence and perspectives on mergers. Journal of Economic Perspectives, I5(2), I03-I20.American Economic Association.https://doi.org/I0.1257/jep.15.2.I03

Asquith, P., Bruner, R. F., \& Mullins, D. W. (1990).Merger returns and the form of financing.

Awogemi, C . A., \& Oguntade, E. S. (2012). Element of Statistical Methods.USA: LAMBERT. Academic Publishing.

Barai, P., \& Mohanty, P. (2014). Role of industry relatedness in performance of Indian acquirers-Long and short run effects. Asia Pacific Journal of Management, 3I(4), 1045-1073.https://doi.org/I0.I007/sI0490-0I4-9372-I

Barkema, H. G., Baum, J. A., \& Mannix, E. A. (2002). Management challenges in a new time. Academy of Management Journal, 45(5), 916-930.

Basu, D., Dastidar, S. G., \& Chawla, D. (2008). Corporate Mergers and Acquisitions in India: Discriminating between Bidders and Targets. Global Business Review, 9(2), 207218.https://doi.org/I0.1177/097215090800900203

Beena, P. (2000). An analysis of mergers in the private corporate sector in India.

Bena, J., \& Li, K. (20I4). Corporate Innovations and Mergers and Acquisitions.Joumal of Finance, 69(5), I923I960.https://doi.org/IO.IIII/jofi.I2059

Bernile, G. (2005). The information content of insiders' forecasts: analysis of the gains from mergers in the 90 s. November 2003.

Bernile, G., \& Lyandres, E. (2019). The effects of horizontal merger operating efficiencies on rivals, customers, and suppliers. Review of Finance, 23(I), II7-I60.

Bhoi, B. K. (2000). Mergers and Acquisitions: An Indian Experience, 2I(I). Retrieved from https://rbidocs.rbi.org.in/rdocs/Publications/Pdfs/I8577.pdf

Bouwman, C. H. S., Fuller, K., \& Nain, A. S. (2009). Market valuation and acquisition quality: Empirical evidence. Review of Financial Studies, 22(2), 633-679. https://doi.org/I0.1093/rfs/hhm073 
Bradley, M., Desai, A., \& Kim, E. H. (I988). Synergistic gains from corporate acquisitions and their division between the stockholders of target and acquiring firms. Journal of financial Economics, 2I(I), 3-40.

Bruner, R., \& Mullins, D. J. (1987). Merger returns and the form of financing. Harvard University.

Byrd, J. W., \& Hickman, K. A. (I992). Do outside directors monitor managers?. Evidence from tender offer bids. Journal of Financial Economics, 32(2), I95-22I. https://doi.org/I0.1016/0304-405X(92)90018-S

Carline, N. F., Linn, S. C., \& Yadav, P. K. (2005). The Influence of Managerial Ownership on the Real Gains in Corporate Mergers and Market Revaluation of Merger Partners: Empirical Evidence.SSRN Electronic Journal.https://doi.org/ I0.2139 ssrn.302606

Carnes, T. A., Black, E. L., \& Jandik, T. (200I). The long-term success of cross-border mergers and acquisitions. Available at SSRN 270288.

Chari, A., Ouimet, P., \& Tesar, L. L. (2004, March). Cross border mergers and acquisitions in emerging markets: The stock market valuation of corporate control. In EFA 2004 Maastricht Meetings Paper (No. 3479).

Chatterjee, S. (1986). Types of synergy and economic value: The impact of acquisitions on merging and rival firms. Strategic Management Journal, 7(2), I I9-I39.https://doi.org/I0.I002/smj.4250070203

Chira, I., García-Feijóo, L., \& Madura, J. (2017). When do managers listen to the market? Impact of learning in acquisitions of private firms. Review of Quantitative Finance and Accounting, 49(2), 5I5543.https://doi.org/I0.1007/sI I I56-016-0599-4

Choi, I. (200I). Unit root tests for panel data. Journal of International Money and Finance 20(2), 249-272.

Cudd, M., \& Duggal, R. (2000). Industry distributional characteristics of financial ratios: An acquisition theory application. Financial Review, 35(I), I05-I20. https://doi.org/I0.I I I /j.I540-6288.2000.tb0I409.x

Cullinan, G., Le Roux, J. M., \& Weddigen, R. M. (2004). When to walk away from a deal. Harvard business review, 82(4), 96-I05.

Cummins, J. D., \& Weiss, M. A. (2004). Consolidation in the European Insurance Industry: Do Mergers and Acquisitions Create Value for Shareholders? Brookings-Wharton Papers on Financial Services, 2004(I), 217-258. https:// doi.org/ I0.1353/pfs.2004.000I

Dickerson, A. P., Gibson, H. D., \& Tsakalotos, E. (1997). The impact of acquisitions on company performance: Evidence from a large panel of UK firms. Oxford Economic Papers, 49(3), 344-36I. https://doi.org/I0.I093/oxfordjournals.oep.a028613

Farjoun, M. (1994). Beyond industry boundaries: Human expertise, diversification and resource-related industry groups. Organization science, 5(2), I85-199.

Fich, E. M., Nguyen, T., \& Officer, M. (2018). Large Wealth Creation in Mergers and Acquisitions.Financial Management, 47(4), 953-99I. https://doi.org/IO.I III/fima.I22I2

Finlay, K., Magnusson, L., \& Schaffer, M. (20I4). WEAK IV: Stata module to perform weak-instrument-robust tests and confidence intervals for instrumental-variable (IV) estimation of linear, probit and to bit models.https:// ideas.repec.org/c/ boc/bocode/s457684.html.

Ghosh, A. (200I). Does operating performance really improve following corporate acquisitions? Journal of Corporate Finance, 7(2), I5I-178. https://doi.org/I0.1016/S0929-I 199(0I)00018-9

Ghosh, A., \& Jain, P. C. (2000). Financial leverage changes associated with corporate mergers. Journal of Corporate Finance, 6(4), 377-402. https://doi.org/I0.2469/dig.v3I.n4.964

Godbole, P. (2013). Mergers, acquisitions and corporate restructuring. Vikas Publishing House Pvt Ltd.

Gujarati, D. (2004). Basic Econometrics. (4 th edtn) The McGraw- Hill Companies.

Hamza, T., Sghaier, A., \& Thraya, M. F. (2016). How do Takeovers Create Synergies? Evidence from France.Studies in Business and Economics, II(I), 54-72. https://doi.org/I0.I5I5/sbe-20I6-0005

Harding, D., \& Rovit, S. (2004). Mastering the merger: Four critical decisions that make or break the deal. Harvard Business Review Press.

Harford, J. (1999). Corporate cash reserves and acquisitions.Journal of Finance, 54(6), 19691997.https://doi.org/I0.II II/0022-I082.00179

Harris, R. S., Franks, J., \& Mayer, C. (I987). Means of Payment in Takeovers: Results for the UK and US (No. w2456). National Bureau of Economic Research.

Harris, R. S., Stewart, J. F., Guilkey, D. K., \& Carleton, W. T. (1982). Characteristics of Acquired Firms: Fixed and Random Coefficients Probit Analyses. Southern Economic Journal, 49(I),I64-I84.

Harrison, J. S., Hitt, M. A., Hoskisson, R. E., \& Ireland, R. D. (2000). Resource Complementarity in Business Combinations: Extending the Logic to Organizational. Journal of Management, 27(6), 679-690. https:// doi.org/ I0.II77/ 0I4920630102700605

Healy, P. M., Palepu, K. G., \& Ruback, R. S. (1992). Does corporate performance improve after mergers?. Journal of financial economics, 3I(2), I35-I75.

Herman, E., \& Lowenstein, L. (1988). The efficiency effects of hostile takeovers. Oxford University Press.

Hogarty, T. (1970). The profitability of corporate mergers. The Journal of Business.https://www.jstor.org/stable/235I78I

Hollander, M., \& Wolfe, D. A. (1973). Nonparametric Statistical methods. London: John Wiley and Sons. 
Huyghebaert, N., \& Luypaert, M. (2013). Sources of Synergy Realization in Mergers and Acquisitions: Empirical Evidence from Non-Serial Acquirers in Europe.International Journal of Financial Research, 4(2).https://doi.org/I0.5430/ijfr.v4n2p49

Ismail, A. (201 I). Does the management's forecast of merger synergies explain the premium paid, the method of payment, and merger motives? Financial Management, 4O(4), 879-9I0.https://doi.org/IO.IIII/j.I755053X.2011.01165.x

Ismail, A., Dbouk, W., \& Azouri, C. (20I4). Does industry-adjusted corporate governance matter in mergers and acquisitions? Corporate Ownership and Control, II(4 Continued 7), 642-656.

Jensen, M. (1986). Agency costs of free cash flow, corporate finance, and takeovers. The American Economic Review.https://www.jstor.org/stable/I818789

Kaplan, S. N., \& Weisbach, M. S. (I992). The Success of Acquisitions: Evidence from Divestitures. The Journal of Finance, 47(I), I07-I38. https://doi.org/I0.I I I /j.I540-626I.I992.tb03980.x

King, D. R., Dalton, D. R., Daily, C. M., \& Covin, J. G. (2004). Meta-analyses of Post-acquisition Performance: Indications of Unidentified Moderators. Strategic Management Journal, 25(2), I87200.https://doi.org/I0.1002/smj.37I

Kruse, T. A., Park, H. Y., \& Suzuki, K. (2003).The Value Of Corporate Diversification: Evidence From Post-Merger Performance In Japan.https://papers.ssrn.com/sol3/papers.cfm?abstract_id=344560

Krzanowski, W. J. (1998). An Introduction to Statistical Modelling. London: Arnold Publishers.

Kuipers, D., Miller, D., \& Patel, A. (2002). Shareholder wealth effects in the cross-border market for corporate control. Working Paper.

Lahey, K., \& Conn, R. (1990). Sensitivity Of Acquiring Firms'returns To Alternative Model Specifications And Disaggregation.Journal of Business Finance \& Accounting. Retrieved from http://www.academia.edu/download/495I7093/j.I468-5957.1990.tb0I 195.x20I6I0I0-6I75-rqvzly.pdf

Lang, L., Stulz, R., \& Walkling, R. (I989). Managerial Performance, Tobin’s Q, And The Gains From Successful Tender Offers.Journal of Finance, 24, I37-154. https://www.researchgate.net/publication/242423169

Lev, B., \& Mandelker, G. (1972). The microeconomic consequences of corporate mergers. Journal of Business,85I04.https:// www.jstor.org/stable/2351600

Limmack, R. J. (I99I). Corporate Mergers and Shareholder Wealth Effects: 1977-1986. Accounting and Business Research, 2I(83), 239-252. https://doi.org/I0.1080/000I4788.1991.9729838

Linn, S. C., \& Switzer, J. A. (200I). Are cash acquisitions associated with better post combination operating performance than stock acquisitions?. Journal of Banking and Finance, 25(6), II I3-I I38. https://doi.org/I0.I0I6/S03784266(00)00I08-4

Loughran, T., \& Vijh, A. M. (1997). Do long-term shareholders benefit from corporate acquisitions?. Journal of Finance, 52(5), I765-I790. https://doi.org/I0.I III/j.I540-626I.I997.tb0274I.x

Loukianova, A., Nikulin, E., \& Vedernikov, A. (2017). Valuing synergies in strategic mergers and acquisitions using the real options approach. Investment Management and Financial Innovations, I4(I), 236247.https://doi.org/I0.2I5II/imfi.I4(I-I).2017.I0

M\&A Statistics by Countries-Institute for Mergers, Acquisitions and Alliances (IMAA). (2019). Retrieved from https://imaa-institute.org/m-and-a-statistics-countries/

Meeks, G. (1977). Disappointing marriage: A study of the gains from merger.

Megginson, W. L., Morgan, A., \& Nail, L. A. (2005). The Determinants of Positive Long-Term Performance in Strategic Mergers: Corporate Focus and Cash. SSRN Electronic Journal, 850I(205).https://doi.org/I0.2139/ssrn.321449

Mitchell, M. L., \& Stafford, E. (2000). Managerial decisions and long-term stock price performance. Journal of Business, 73(3), 287-329. https://doi.org/I0.1086/209645

Moeller, S., \& Schlingemann, F. (2004). Are cross-border acquisitions different from domestic acquisitions? Evidence on stock and operating performance for US acquirers.Journal of Banking and Finance.https:// papers.ssrn.com/ sol3 / papers.cfm? abstract_id=3II543

Mohanty, P., \& Mishra, S. (20II). Run-up in Stock Prices Prior to Merger \& Acquisitions Announcements: Evidence from India. NSE Working Paper, January, 8-9.

Mooney, T., \& Shim, H. (2015). Does Financial Synergy Provide a Rationale for Conglomerate Mergers? Asia-Pacific Journal of Financial Studies, 44(4), 537-586. https://doi.org/I0.I I I I/ajfs.I2099

Morag, O. (201I). The Role of Speed of Integration in the Integration Effectiveness and Mergers \& Acquisitions Success. Retrieved from http://pea.lib.pte.hu/bitstream/handle/pea/II63/Omri Morag - tezisek.pdf?sequence=2

Mulherin, J. H., \& Boone, A. L. (2000). Comparing Acquisitions and Divestitures. Journal of Corporate Finance.https://www.sciencedirect.com/science/article/pii/S09291 19900000109

Newey, W. K. (1987). Efficient estimation of limited dependent variable models with endogenous explanatory variables.Journal of Econometrics, 36(3), 23I-250.

Parrino, J. D., \& Harris, R. S. (I999). Takeovers, Management Replacement, and Post-acquisition Operating Performance: Some Evidence from the I980s. Journal of Applied Corporate Finance, II(4), 8896.https://doi.org/I0.I I I I/j.I745-6622.1999.tb00518.x 
Pastena, V., \& Ruland, W. (1986). The Merger/Bankruptcy Alternative. The Accounting Review, 6I(2), 288-30I.

Pazarskis, M., Vogiatzogloy, M., Christodoulou, P., \& Drogalas, G. (2006). Exploring the improvement of corporate performance after mergers-the case of Greece.Int. Res. J. Financ. Econ. Retrieved from http://www.drogalas.gr/uploads/publications/Exploring_the_improvement_of_corporate_performance_after_ mergers_-_the_case_of_Greece.pdf

Peterson, D., \& Peterson, P. (I99I). The medium of exchange in mergers and acquisitions.Journal of Banking \& Finance.https://www.sciencedirect.com/science/article/pii/037842669190074V

Philippatos, G., Choi, D., \& Dowling, W. (1985). Effects of mergers on operational efficiency: A study of the S\&L industry in transition. Northeast Journal of Business \& Economics, II, I-I4.

Powell, R. G., \& Stark, A. W. (2005). Does operating performance increase post-takeover for UK takeovers? A comparison of performance measures and benchmarks.Journal of Corporate Finance, II, 293317.https://doi.org/I0.I0I6/j.jcorpfin.2003.06.00I

Rajeshkumar, B., \& Rajib, P. (2007). Characteristics of merging firms in India: An empirical examination. Vikalpa, 32(I), 27-44. https://doi.org/IO.I I77/0256090920070103

Ramaswamy, K., \& Salatka, W. (1996). Impact of Mergers on Long Term Operating Performance of the Combined Firm. Working Paper.

Ramaswamy, K. P., \& Waegelein, J. F. (2003). Firm financial performance following mergers.Review of Quantitative Finance and Accounting, 20(2), I I5-I26. https://doi.org/I0.1023/A:1023089924640

Rau, P. R., \& Vermaelen, T. (1998). Glamour, Value and the Post-acquisition Performance of Acquiring Firms.Journal of Financial Economics, 49, 223-253. https://www.researchgate.net/publication/228839525

Ravenscraft, D., \& Scherer, F. (20II). Mergers, sell-offs, and economic efficiency.

Rivers, D., \& Vuong,Q. H. (1988). Limited information estimators and exogeneity tests for simultaneous probit models. Journal of Econometrics 39(3), 347-366.

Rozen-Bakher, Z. (2018). Comparison of merger and acquisition (M\&A) success in horizontal, vertical and conglomerate M\&As: industry sector vs. services sector. Service Industries Journal, 38(7-8), 492-5I8. https://doi.org/I0.1080/02642069.2017.1405938

Servaes, H. (199I). Tobin's Q and the Gains from Takeovers. The Journal of Finance, 46(I), 409-419. https:// doi.org/ I0.IIII/j.I540-626I.199I.tb03758.x

Sharma, D. S., \& Ho, J. (2002). The impact of acquisitions on operating performance: Some Australian evidence. Journal of Business Finance and Accounting, 29(I-2), I55-200. https://doi.org/IO.I I I / I468-5957.00428

Sinha, D. N., Kaushik, D. K. ., \& Chaudhary, T. (2010). Measuring Post Merger and Acquisition Performance: An Investigation of Select Financial Sector Organizations in India. International Journal of Economics and Finance, 2(4), I90-200. https:// doi.org/I0.5539/ijef.v2n4pI90

Smith, R. L., \& Kim, J. H. (1994). The Combined Effects of Free Cash Flow and Financial Slack on Bidder and Target Stock Returns. The Journal of Business, 67(2), 281.https://doi.org/10.1086/296633

Sudarsanam, S., Holl, P., \& Salami, A. (1996). Shareholder wealth gains in mergers: Effect of synergy and ownership structure. Journal of Business Finance and Accounting, 23(5-6), 673-698. https://doi.org/I0.I I II/j.I4685957.1996.tb01 I48.x

Switzer, J. (1996). Evidence on real gains in corporate acquisitions.Journal of Economics and Business.https://www.sciencedirect.com/science/article/pii/SOI486I959600033I

Tanriverdi, H., \& Uysal, V. B. (20II). Cross-business information technology integration and acquirer value creation in corporate mergers and acquisitions. Information Systems Research, 22(4), $703-$ 720.https://doi.org/IO.I287/isre.I090.0250

Tanriverdi, H., \& Venkatraman, N. (2005). Knowledge relatedness and the performance of multibusiness firms. In Strategic Management Journal, 26(2), 97-I 19. https://doi.org/I0.1002/smj.435

Tremblay, A. (2017). Cultural Differences, Synergies and Mergers and Acquisitions.SSRN Electronic Journal.https://doi.org/I0.2139/ssm.2895110

Ucla: Statistical Consulting Group. (n.d.). Logistic Regression Analysis | Stata Annotated Output. Retrieved May I4, 2020, from https://stats.idre.ucla.edu/stata/output/logistic-regression-analysis/

Varaiya, N. P., \& Ferris, K. R. (1987). Overpaying in Corporate Takeovers: The Winner's Curse.Financial Analysts Journal, 43(3), 64-70.https://doi.org/I0.2469/faj.v43.n3.64

Yeh, T., \& Hoshino, Y. (2002). Productivity and operating performance of Japanese merging firms: Keiretsu-related and independent mergers. Japan and the World Economy, I4(3), 347-366. https://doi.org/I0.I0I6/S0922I425(0I)0008I-0 
Notes

Note I. Tangible Asset is defined as a total fixed asset. (Source: Bloomberg Terminal)

Note 2. Due to the paucity of space, the result is not mentioned here. The Result of the stationary test is available on request.

Appendix A. Distribution of sample across sectors.

\begin{tabular}{lll}
\hline Sectors & Acquirer Industry Sector & Target Industry Sector \\
\hline Industrial & 30 & 23 \\
\hline Basic Materials & 28 & 29 \\
\hline Consumer, Cyclical & 24 & 27 \\
\hline Consumer, Non-cyclical & 17 & 21 \\
\hline Technology & 9 & 7 \\
\hline Energy & 4 & 2 \\
\hline Utilities & 4 & 4 \\
\hline Communications & 2 & 6 \\
\hline Diversified & 2 & Source: Bloomberg Terminal
\end{tabular}

Appendix B. Definition of the Variables

\begin{tabular}{|c|c|c|c|}
\hline S.No. & Variable & Symbol & Definition of the variable \\
\hline I & $\begin{array}{l}\text { Mode of Payment } \\
\text { dummy }\end{array}$ & $\begin{array}{l}\text { Payment_Cash } \\
\text { Variable) }\end{array}$ & $\begin{array}{l}\text { Value I if cash is the method of payment for the deal } \\
\text { and } 0 \text { otherwise. }\end{array}$ \\
\hline 2 & $\begin{array}{l}\text { Mode of Payment } \\
\text { dummy }\end{array}$ & $\begin{array}{l}\text { Payment_Equity (Dependent } \\
\text { Variable) }\end{array}$ & $\begin{array}{l}\text { Value I if the method of payment is equity and } 0 \\
\text { otherwise. }\end{array}$ \\
\hline 3 & $\begin{array}{l}\text { Relatedness of industry } \\
\text { dummy }\end{array}$ & $\begin{array}{l}\text { Industry_Relatedness } \\
\text { (Dependent Variable) }\end{array}$ & $\begin{array}{l}\text { Value I if the acquisition is horizontal and } 0 \\
\text { otherwise. }\end{array}$ \\
\hline 4 & Free Cash Flow & Cf_Free_Cash_Flow & $\begin{array}{l}\text { It is the cash that a firm may yield after outlining the } \\
\text { capital necessary to sustain or extend its assets. }\end{array}$ \\
\hline 5 & $\begin{array}{lr}\text { Earnings } & \text { before } \\
\text { interest, } & \text { taxes, } \\
\text { depreciation, } & \text { and } \\
\text { amortization } & \end{array}$ & Ebitda & $\begin{array}{l}\text { Net income }+ \text { taxes }+ \text { depreciation }+ \text { interest } \\
+ \text { amortization) } \\
\text { It is used to evaluate and equate profitability among } \\
\text { firms since the consequences of accounting and } \\
\text { financing resolutions are excluded by it. }\end{array}$ \\
\hline 6 & Current Market Cap & Cur_Mkt_Cap & $\begin{array}{l}\text { The total current market value of all the outstanding } \\
\text { shares of the firm. }\end{array}$ \\
\hline 7 & Working Capital & Working_Capital & Current Assets minus Current Liabilities \\
\hline 8 & $\begin{array}{l}\text { Short and Long Term } \\
\text { Debt }\end{array}$ & Short_And_Long_Term_Debt & Summation of Short and Long Term Debt. \\
\hline 9 & Net Debt & Net_Debt & $\begin{array}{l}\text { Indicates the company's overall debt. Net of liabilities } \\
\text { and debts along with cash and other similar liquid } \\
\text { assets. }\end{array}$ \\
\hline IO & Financial Leverage & Fncl_Lvrg & Average assets/Average equity \\
\hline II & $\begin{array}{l}\text { Degree of Financial } \\
\text { Leverage }\end{array}$ & Degree_Financial_Leverage & $\begin{array}{l}\text { The affect a given amount of financial leverage has on } \\
\text { a firm's earnings. }\end{array}$ \\
\hline 12 & $\begin{array}{l}\text { Net Fixed Assets } 5 \\
\text { Year Growth }\end{array}$ & $\begin{array}{l}\text { Net_Fixed_Assets_5_Year_Gro } \\
\text { wth }\end{array}$ & $\begin{array}{l}\text { The geometric growth rate over five years in net fixed } \\
\text { assets. }\end{array}$ \\
\hline 13 & $\begin{array}{l}\text { Gross Fixed Asset } \\
\text { Turnover }\end{array}$ & Gross_Fix_Asset_Turn & Net sales / gross fixed assets. \\
\hline I4 & $\begin{array}{l}\text { Personnel Expenses per } \\
\text { Employee }\end{array}$ & Personnel_Expn_Per_Employee & Personnel expenses/number of employees. \\
\hline I5 & $\begin{array}{l}\text { R \& D Expenditure to } \\
\text { Net Sales }\end{array}$ & Rd_Expend_To_Net_Sales & $\begin{array}{l}\text { Research and development (R\&D) expenditures as a } \\
\text { percentage of the net sales. }\end{array}$ \\
\hline 16 & Goodwill to Assets \% & Goodwill_Assets_ & Goodwill / total assets. \\
\hline
\end{tabular}




\begin{tabular}{|c|c|c|c|}
\hline I7 & EBITDA Margin & Ebitda_To_Revenue & The ratio of EBITDA to revenue. \\
\hline 18 & $\begin{array}{l}\text { Cash Flow to Net } \\
\text { Income }\end{array}$ & Cash_Flow_To_Net_Inc & $\begin{array}{l}\text { A firm's total net income that is accessible as cash for } \\
\text { investing and financing the current business. }\end{array}$ \\
\hline 19 & Operating Margin & Oper_Margin & Operating Income (Losses) / Total Revenue ${ }^{*}$ I00 \\
\hline \multirow[t]{3}{*}{20} & Total Operating & Total_Opex_As_A_Percentage_ & Measures the total operating expenses (including the \\
\hline & Expenses as a & Sales & cost of goods sold and selling, general, and \\
\hline & Percentage of Sales & & \\
\hline $2 \mathrm{I}$ & INVENT_TURN & Invent_Turn & $\begin{array}{l}\text { The ratio shows the number of times a firm's inventory } \\
\text { is sold and gets replaced over a period. }\end{array}$ \\
\hline 22 & NET INCOME & Net_Income & $\begin{array}{l}\text { Amount of profit of the firm after settling all of its } \\
\text { expenses. }\end{array}$ \\
\hline 23 & $\begin{array}{l}\text { Net Debt to FCFF } \\
\text { (Free Cash Flow to } \\
\text { Firm) }\end{array}$ & Net_Debt_To_Ffff & $\begin{array}{l}\text { It is a leverage ratio indicating a firm's ability to pay } \\
\text { off its debts after deducting the cash outlays necessary } \\
\text { to maintain its current operation. }\end{array}$ \\
\hline 24 & Risk Premium & Risk_Premium & $\begin{array}{l}\text { An investor requires an average incremental return as } \\
\text { compensation for investing in equities rather than as a } \\
\text { risk-free instrument. }\end{array}$ \\
\hline 25 & Quick ratio & Quick_Ratio & $\begin{array}{l}\text { Cash and Near Cash }+ \text { Account Receivables }+ \text { Short } \\
\text { Term Investments / Current Liabilities }\end{array}$ \\
\hline 26 & Total Assets & Bs_Tot_Asset & Sum of short and long-term assets. \\
\hline 27 & $\begin{array}{l}\text { Operating Income or } \\
\text { Losses }\end{array}$ & Is_Oper_Inc & $\begin{array}{l}\text { (Net Sales }+ \text { Other Operating Income })- \text { (Cost of } \\
\text { Goods Sold }+ \text { Other Operating Expenses })\end{array}$ \\
\hline 28 & Free Cash Flow Yield & Free_Cash_Flow_Yield & Return expected per share. \\
\hline 29 & $\begin{array}{l}\text { Return on Common } \\
\text { Equity }\end{array}$ & Return_Com_Eqy & $\begin{array}{l}\text { Measure how much income a corporation earns, in } \\
\text { percentage, with the money shareholders invested. }\end{array}$ \\
\hline 30 & Asset Turnover & Asset_Turnover & Amount of sales or revenues generated per assets. \\
\hline $3 I$ & Capitalization Ratio & Capitalization_Ratio & $\begin{array}{l}\text { Long-term debt as a percentage of total equity and } \\
\text { long-term debt, including preferred equity and } \\
\text { minority share. }\end{array}$ \\
\hline 32 & $\begin{array}{l}\text { Long } \\
\text { Investments }\end{array}$ & Bs_Long_Term_Investments & Includes long-term investments. \\
\hline 33 & Return on Capital & Return_On_Cap & $\begin{array}{l}\text { Measures, in percentage, the return generated by an } \\
\text { investment for capital contributors. }\end{array}$ \\
\hline 34 & Tobin's Q Ratio & Tobin_QRatio & $\begin{array}{l}\text { The ratio of a firm's market value to the cost of } \\
\text { replacement of its assets. }\end{array}$ \\
\hline 35 & $\begin{array}{l}\text { Normalized Net } \\
\text { Income Growth }\end{array}$ & $\begin{array}{l}\text { Normalized_Net_Income_Grow } \\
\text { th }\end{array}$ & Year over year growth in normalized net income. \\
\hline 36 & $\begin{array}{l}\text { Market Cap To Net } \\
\text { Revenue }\end{array}$ & Mkt_Cap_To_Revenue & $\begin{array}{l}\text { Market Value of Equity/Trailing I2 Month Net } \\
\text { Revenue. }\end{array}$ \\
\hline 37 & Long Term Debt & Bs_Lt_Borrow & $\begin{array}{l}\text { All interest-bearing financial obligations which are not } \\
\text { due within a year. }\end{array}$ \\
\hline 38 & $\begin{array}{l}\text { Total Debt to Total } \\
\text { Assets }\end{array}$ & Tot_Debt_To_Tot_Asset & The total amount of debt relative to assets. \\
\hline 39 & $\begin{array}{l}\text { Total Debt and } \\
\text { Preferred Equity }\end{array}$ & $\begin{array}{l}\text { Total_Debt_And_Preferred_Eq } \\
\text { uity }\end{array}$ & $\begin{array}{l}\text { Sum of short term borrowing, long term borrowing, } \\
\text { and preferred equity at the end of the period end date. }\end{array}$ \\
\hline 40 & $\begin{array}{l}\text { Total Debt to Total } \\
\text { Equity }\end{array}$ & Totaldebttototalequity & Total debt/total shareholders' equity. \\
\hline $4 \mathrm{I}$ & PRETAX MARGIN & Pretax_Margin & $\begin{array}{l}\text { Earnings before tax for a firm as a proportion of } \\
\text { overall income or profits. }\end{array}$ \\
\hline 42 & Net Asset & Net_Assets & $\begin{array}{l}\text { Total Assets - Current Liabilities - Long-term } \\
\text { Borrowings - Other Long-term Liabilities }\end{array}$ \\
\hline 43 & $\begin{array}{l}\text { Cash and } \\
\text { Equivalents }\end{array}$ & Cce_And_Sti_Detailed & $\begin{array}{l}\text { Cash in vault }+ \text { Deposits in banks }+ \text { short term } \\
\text { investments having a maturity of less than } 90 \text { days. }\end{array}$ \\
\hline 44 & $\begin{array}{l}\text { Revenue Sequential } \\
\text { Growth }\end{array}$ & Revenue_Sequential_Growth & Period to period sequential growth rate in revenue. \\
\hline
\end{tabular}


Appendix C. Correlation Matrix for Model I

\begin{tabular}{|c|c|c|c|c|c|c|c|c|}
\hline & $\begin{array}{l}\text { Cur_Mkt } \\
\text { _Cap }\end{array}$ & $\begin{array}{l}\text { Net_Inco } \\
\text { me }\end{array}$ & $\begin{array}{l}\text { Net_Deb } \\
\text { t_To_Ffc } \\
f\end{array}$ & $\begin{array}{l}\text { Risk_Premi } \\
\text { um }\end{array}$ & $\begin{array}{l}\text { Opcfroa_H } \\
\text { ealy }\end{array}$ & $\begin{array}{l}\text { Rd_Expend } \\
\text { To_Net_S } \\
\text { ales }\end{array}$ & $\begin{array}{l}\text { Net_De } \\
\text { bt }\end{array}$ & $\begin{array}{l}\text { Goodwill } \\
\text { _Assets_ }\end{array}$ \\
\hline $\begin{array}{l}\text { Cur_Mkt_Ca } \\
\mathrm{p}\end{array}$ & $\bar{I}$ & & & & & & & \\
\hline Net_Income & 0.182 & $\mathrm{I}$ & & & & & & \\
\hline $\begin{array}{l}\text { Net_Debt_T } \\
\text { o_Ffef }\end{array}$ & -0.053 & -0.067 & $\mathrm{I}$ & & & & & \\
\hline $\begin{array}{l}\text { Risk_Premiu } \\
\text { m }\end{array}$ & -0.060 & -0.078 & 0.009 & $\mathrm{I}$ & & & & \\
\hline $\begin{array}{l}\text { Opcfroa_Hea } \\
\text { ly }\end{array}$ & 0.016 & 0.025 & -0.009 & -0.021 & $\mathrm{I}$ & & & \\
\hline $\begin{array}{l}\text { Rd_Expend_- } \\
\text { To_Net_Sale } \\
\text { s }\end{array}$ & 0.135 & 0.024 & -0.017 & $-0.08 \mathrm{I}$ & -0.024 & $\bar{I}$ & & \\
\hline Net_Debt & -0.120 & 0.034 & 0.037 & 0.025 & -0.059 & -0.098 & $\bar{I}$ & \\
\hline $\begin{array}{l}\text { Goodwill_As } \\
\text { sets__ }\end{array}$ & 0.134 & $0.05 \mathrm{I}$ & -0.034 & -0.026 & 0.020 & -0.044 & 0.122 & $\mathrm{I}$ \\
\hline
\end{tabular}

Appendix D. Correlation Matrix for Model 2

\begin{tabular}{|c|c|c|c|c|c|c|c|c|c|}
\hline & $\begin{array}{l}\text { Net_Ass } \\
\text { ets }\end{array}$ & $\begin{array}{l}\text { Workin } \\
\text { g_Capit } \\
\text { al }\end{array}$ & $\begin{array}{l}\text { Cf_Free } \\
\text { Cash_- } \\
\text { Flow }\end{array}$ & $\begin{array}{l}\text { Opcfroa } \\
\text { _Healy }\end{array}$ & $\begin{array}{l}\text { Invent__ } \\
\text { Turn }\end{array}$ & $\begin{array}{l}\text { Cce_And_- } \\
\text { Sti_Detaile } \\
\text { d }\end{array}$ & $\begin{array}{l}\text { Quick__ } \\
\text { Ratio }\end{array}$ & Ebitda & $\begin{array}{l}\text { Cash_Flo } \\
\text { w_To_N } \\
\text { et_Inc }\end{array}$ \\
\hline Net_Assets & $\mathrm{I}$ & & & & & & & & \\
\hline $\begin{array}{l}\text { Working_Ca } \\
\text { pital }\end{array}$ & 0.264 & $\mathrm{I}$ & & & & & & & \\
\hline $\begin{array}{l}\text { Cf_Free_Cas } \\
\text { h_Flow }\end{array}$ & 0.004 & 0.018 & $\mathrm{I}$ & & & & & & \\
\hline $\begin{array}{l}\text { Opcfroa_He } \\
\text { aly }\end{array}$ & $-0.02 \mathrm{I}$ & 0.017 & 0.093 & $\bar{I}$ & & & & & \\
\hline Invent_Turn & 0.162 & 0.095 & $0.01 \mathrm{I}$ & -0.008 & $\mathrm{I}$ & & & & \\
\hline $\begin{array}{l}\text { Cce_And_Sti } \\
\text { _Detailed }\end{array}$ & 0.178 & 0.164 & 0.004 & -0.025 & 0.029 & $\mathrm{I}$ & & & \\
\hline Quick_Ratio & 0.170 & 0.139 & -0.039 & -0.010 & 0.109 & 0.149 & $\mathrm{I}$ & & \\
\hline Ebitda & 0.144 & 0.080 & 0.140 & 0.002 & 0.088 & $-0.14 \mathrm{I}$ & -0.025 & $\mathrm{I}$ & \\
\hline $\begin{array}{l}\text { Cash_Flow_- } \\
\text { To_Net_Inc }\end{array}$ & 0.154 & 0.006 & -0.020 & -0.016 & 0.005 & 0.057 & 0.048 & -0.156 & $\mathrm{I}$ \\
\hline
\end{tabular}

Appendix E. Correlation Matrix for Model 3

\begin{tabular}{|c|c|c|c|c|c|c|}
\hline $\begin{array}{l}\text { Cur_Mk } \\
\text { t_Cap }\end{array}$ & $\begin{array}{l}\text { Invent_ } \\
\text { Turn }\end{array}$ & $\begin{array}{l}\text { Total_O } \\
\text { pex_As_ } \\
\text { A_Percen } \\
\text { tage_Sales }\end{array}$ & $\begin{array}{l}\text { Free_Cash_Fl } \\
\text { ow_Yield }\end{array}$ & $\begin{array}{l}\text { Return_O } \\
\text { n_Cap }\end{array}$ & $\begin{array}{l}\text { Normalized } \\
\text { _Net_Inco } \\
\text { me_Growth }\end{array}$ & $\begin{array}{l}\text { Oper_Mar } \\
\text { gin }\end{array}$ \\
\hline
\end{tabular}

\begin{tabular}{lll}
\hline Cur_Mkt_Cap & I & \\
\hline Invent_Turn & 0.197 & I \\
\hline
\end{tabular}




\begin{tabular}{|c|c|c|c|c|c|c|c|}
\hline $\begin{array}{l}\text { Total_Opex_As_A_Per } \\
\text { centage_Sales }\end{array}$ & -0.054 & -0.023 & $\mathrm{I}$ & & & & \\
\hline Free_Cash_Flow_Yield & -0.158 & -0.03 & -0.134 & $\mathrm{I}$ & & & \\
\hline Return_On_Cap & 0.230 & 0.166 & -0.078 & -0.0546 & $\mathrm{I}$ & & \\
\hline $\begin{array}{l}\text { Normalized_Net_Inco } \\
\text { me_Growth }\end{array}$ & -0.070 & 0.097 & O.II4 & -0.005 & -0.005 & $\mathrm{I}$ & \\
\hline Oper_Margin & 0.039 & 0.013 & -0.273 & 0.144 & 0.080 & -0.054 & $\mathrm{I}$ \\
\hline
\end{tabular}

Appendix F. Correlation Matrix for Model 4

\begin{tabular}{|c|c|c|c|c|c|c|c|c|c|c|}
\hline & $\begin{array}{l}\text { Cur_M } \\
\text { kt_Cap }\end{array}$ & $\begin{array}{l}\text { Bs_Lt_B } \\
\text { orrow }\end{array}$ & $\begin{array}{l}\text { Free_Ca } \\
\text { sh_Flow } \\
\text { _Yield }\end{array}$ & $\begin{array}{l}\text { Net_In } \\
\text { come }\end{array}$ & $\begin{array}{l}\text { Quick__ } \\
\text { Ratio }\end{array}$ & $\begin{array}{l}\text { Short_An } \\
\text { d_Long_- } \\
\text { Term_De } \\
\text { bt }\end{array}$ & $\begin{array}{l}\text { Total_De } \\
\text { bt_And__ } \\
\text { Preferred } \\
\text { Equity }\end{array}$ & $\begin{array}{l}\text { Rd_Exp } \\
\text { end_To } \\
\text { _Net_S } \\
\text { ales }\end{array}$ & $\begin{array}{l}\text { Bs_T } \\
\text { ot_As } \\
\text { set }\end{array}$ & $\begin{array}{l}\text { Degree_Fi } \\
\text { nancial_Le } \\
\text { verage }\end{array}$ \\
\hline $\begin{array}{l}\text { Cur_Mkt__ } \\
\text { Cap }\end{array}$ & I & & & & & & & & & \\
\hline $\begin{array}{l}\text { Bs_Lt_Bor } \\
\text { row }\end{array}$ & -0.19 & $\mathrm{I}$ & & & & & & & & \\
\hline $\begin{array}{l}\text { Free_Cash } \\
\text { _Flow_Yie } \\
\text { ld }\end{array}$ & $-0.15 \mathrm{I}$ & 0.129 & I & & & & & & & \\
\hline $\begin{array}{l}\text { Net_Inco } \\
\text { me }\end{array}$ & 0.172 & -0.127 & $-0.09 \mathrm{I}$ & I & & & & & & \\
\hline $\begin{array}{l}\text { Quick_Rat } \\
\text { io }\end{array}$ & 0.006 & -0.026 & -0.058 & 0.074 & $\mathrm{I}$ & & & & & \\
\hline $\begin{array}{l}\text { Short_And } \\
\text { _Long_Te } \\
\text { rm_Debt }\end{array}$ & -0.122 & 0.327 & 0.130 & $-0.09 \mathrm{I}$ & -0.108 & $\mathrm{I}$ & & & & \\
\hline $\begin{array}{l}\text { Total_Deb } \\
\text { t_And_Pre } \\
\text { ferred_Equ } \\
\text { ity }\end{array}$ & -0.29 & 0.787 & $0.17 \mathrm{I}$ & -0.19 & -0.14 & 0.205 & I & & & \\
\hline $\begin{array}{l}\text { Rd_Expen } \\
\text { d_To_Net } \\
\text { _Sales }\end{array}$ & 0.137 & -0.149 & -0.034 & 0.055 & 0.029 & -0.124 & -0.15 & I & & \\
\hline $\begin{array}{l}\text { Bs_Tot_As } \\
\text { set }\end{array}$ & 0.162 & 0.130 & -0.073 & 0.02 & 0.013 & 0.162 & 0.240 & -0.028 & $\mathrm{I}$ & \\
\hline $\begin{array}{l}\text { Degree_Fi } \\
\text { nancial_Le } \\
\text { verage }\end{array}$ & -0.02 & 0.069 & $-0.00 \mathrm{I}$ & -0.04 & -0.02 & 0.060 & 0.069 & $0.02 \mathrm{I}$ & 0.05 & 1.0000 \\
\hline
\end{tabular}

\section{Copyrights}

Copyright for this article is retained by the author(s), with first publication rights granted to the journal. This is an openaccess article distributed under the terms and conditions of the Creative Commons Attribution license (http://creativecommons.org/licenses/by/4.0/). 